\title{
シングルデッキ型浮屋根を有する円筒液体貯槽の非線形スロッシング解析 NONLINEAR SLOSHING ANALYSIS OF CYLINDRICAL LIQUID STORAGE TANK WITH SINGLE-DECK TYPE FLOATING ROOF
}

\author{
山本憲司*, 皆川洋一** \\ Kenji YAMAMOTO and Youichi MINAKAWA
}

\begin{abstract}
This paper proposes a finite element method for nonlinear sloshing analysis of the liquid storage tanks with the single-deck type floating roof. The elastic finite elements with geometrical non-linearity are applied on modeling the floating roof, and the liquid elements are formulated based on the potential theory and the variational principle. The interaction problem of the elastic body and the fluid is formulated based on the variational principle, therefore the equilibrium equations are simply derived.

The 100,000kl tank struck by the 2003 Tokachi-oki earthquake is modeled for the numerical example, and the seismic response analysis is performed. As this result, it is found that the high-order mode vibration, of which deformation is the 1st radial mode and the 3 rd circumferential mode, might occur as the second mode vibration grows on the floating roof, and large stress such that the pontoon is collapsed might appear in the floating roof.
\end{abstract}

Keywords : nonlinear sloshing, floating roof, liquid storage tank, single-deck, finite element method, variational principle 非線形スロッシング, 浮屋根, 液体貯槽, シングルデッキ，有限要素法，変分原理

1 はじめに

2003年9月に発生した十勝沖地震では、苫小牧市にある石油精製 の製油所で、大型タンクにスロッシングを起こし、浮屋根の沈没や タンクの全面火災など多くの被害が発生した1)。近い将来発生する と言われている東海・東南海地震では、長周期成分を多く含んだ地 震動であることが予測されており、一般に長周期帯に共振域をもつ 大型タンクにおけるスロッシング対策が急務の課題となっている。 現存するタンクの多くは浮屋根が設置されている。浮屋根の形式に はシングルデッキ型とダブルデッキ型がある。十勝沖地震では主に シングルデッキ型浮屋根に大きな被害があり、特に 10 万 $\mathrm{k} 1$ 級の大型 タンクではスロッシング二次モードによる共振が原因であると報告 されている2)。2005年4月に消防法告示の改正 ${ }^{3)}$ が行われ浮屋根の耐震 性能確保のための技術基準が示されたが、この報告を受けて二次 モードの応答を評価して浮屋根を設計することが義務付けられた。

シングルデッキ型浮屋根は、外周に浮力を得るためのポンッー ン（浮き室）が配置されており、デッキ部分は一枚の鋼板で構成さ れる。ポンッーンの剛性に比べるとデッキ部の面外剛性は極端に小 さい。この為、浮屋根が二次モードで共振する時、剛性の高いポン ッーンはコンプレッションリングの役割を果たし、波高によって デッキ部分に大変形が生起し、膜力が発生する。この膜力によって
浮屋根には幾何剛性が付与され、浮屋根全体の見掛けの剛性が高く なることで応答の低減効果があると言われている。しかし、この力 学挙動を数值解析で扱うには、流体と弾性体との煩雑な非線形相互 作用問題を扱う必要がある。

浮屋根と流体の相互作用問題を扱った既往の研究は数が少ない。 線形問題を扱った初期の研究では、浮屋根を質量のない剛体と仮定 したNakagawa ${ }^{4)}$ の研究がある。また、山本5) は新潟地震の石油貯槽の 事故を分析するために同様の問題を扱った。坂井ら $\left.{ }^{6}\right)$ は浮屋根を弾 性体として有限要素法による解析を行い、浮屋根の質量や剛性がス ロッシング応答に与える影響について初めて詳細に調査した。松井 7),8) は浮屋根式円筒タンクの解析解を導出し、十勝沖地震で被災した タンクの解析を行っている。これらの線形理論による方法では前述 のシングルデッキ型浮屋根の応答を予測することは困難である。浮 屋根と流体の非線形相互作用を扱った研究では、三浦9らは汎用の有 限要素解析ソフトを利用した詳細な非線形解析を行っている。内海 $ら^{10), 11)}$ は浮屋根の有限要素モデルのモード展開式を利用したガラーキ ン法による定式化を行い10)、浮屋根の幾何学的非線形性を近似的に 考慮して前述の浮屋根の二次モード応答を解析している11)。しかし これらの研究では解析例は限られており、浮屋根の幾何学的非線形 性が応答に与える影響について把握するには未だ不十分である。ま
* 鹿児島大学大学院理工学研究科 助教 $\cdot$ 博士 (工学)

** 鹿児島大学大学院理工学研究科 教授. 工博
Assistant Prof., Graduate School of Science and Engineering, Kagoshima Univ., Dr. Eng. Prof., Graduate School of Science and Engineering, Kagoshima Univ., Dr. Eng. 
た、解析手法についても合理的な手法が確立されているとは言い難い。

本報はシングルデッキ型浮屋根を有する円筒液体貯槽における非 線形スロッシング解析手法の提案並びにその力学性状の把握を目的 とし、有限要素法による流体と浮屋根弾性体との非線形相互作用問 題の定式化を行う。流体要素には、著者らが既報12),13)で提案した速 度ポテンシャルを自由表面変位に追従する移動座標系で表現する方 法を用いる。また弾性体と流体の相互作用については、著者らの一 人が文献14)で示した流体場圧力の体積積分と弾性体ポテンシャル エネルギーの和を汎関数として用い、変分原理に基づいて釣合式を 導出する。数值解析では、十勝沖地震で被災した 10 万k1タンクと同 規模の数值解析モデルを設定し、正弦波入力による二次モード応答 性状並びに十勝沖地震の記録デー夕による地震応答性状について調 査を行った結果について報告する。

\section{2 数值解析方法}

\section{1 浮屋根式タンクのモデル化の概要}

シングルデッキ型浮屋根式タンクにおける固有周期は、浮屋根の 曲げ岡性が非常に小さいために、自由液面の場合と殆ど変わらない 6),7)。この為、デッキ部を曲げ剛性の無い膜要素によってモデル化 し、デッキの境界に配置されるポンツーンは梁要素によってモデル 化する（図1左）。また、線形解析により浮屋根の質量の影響は小 さいことが知られている為6、質量は考慮しない。

梁要素と側壁との間には隙間を設け、支持条件は図1右上に示す ように梁要素節点の4箇所をローラ支持とする。実際のタンクでは 浮屋根と側壁の間にシール材が設けられるため、梁要素節点とその 外周にある側壁上節点のz方向変位が等しいものとしてモデル化す る(図1右下)。

\section{2 流体要素及び弾性体要素}

流体場の要素には、8 節点アイソパラメトリック体要素を採用す る。浮屋根の変位に追従して、流体要素の形状が自ずと変化するよ うに、流体場の節点座標を膜要素や梁要素などの弾性体節点変位の 関数として与える（図2）。ここでは、流体要素節点 $i$ の座標 $\left(x_{e i}, y_{e i}, z_{e i}\right)$ が、その上部にある弾性体要素節点変位 $\left(u_{e i}, v_{e i}, w_{e i}\right)$ の線 形関数で表せるものとし、次式のような節点の移動ルールを与える。

$$
\begin{aligned}
& \mathbf{x}_{e}=\mathbf{x}_{e}^{0}+\mathbf{H}_{x} \mathbf{u}_{e}, \mathbf{y}_{e}=\mathbf{y}_{e}^{0}+\mathbf{H}_{y} \mathbf{v}_{e}, \mathbf{z}_{e}=\mathbf{z}_{e}^{0}+\mathbf{H}_{z} \mathbf{w}_{e} \\
& \mathbf{H}_{x}=\mathbf{I}_{8 \times 8}, \mathbf{H}_{y}=\mathbf{I}_{8 \times 8}, \mathbf{H}_{z}=\left[\begin{array}{ccc}
\left(h+z_{e 1}^{0}\right) / h & & 0 \\
O & \ddots & \left(h+z_{e 8}^{0}\right) / h
\end{array}\right]
\end{aligned}
$$

ここに、例えば $\mathbf{x}_{e}=\left(x_{e l}, \cdots, x_{e 8}\right)^{T}$ であり、 $h(>0)$ は自然状態におけ る水高を、 $\left(x_{e i}^{0}, y_{e i}^{0}, z_{e i}^{0}\right)$ は自然状態における節点座標を表す。節点座 標の原点は静止自由表面（浮屋根との境界面）上に設ける。

要素節点における速度ポテンシャルを $\varphi_{e}=\left(\varphi_{e 1}, \cdots, \varphi_{e 8}\right)^{T}$ と表し、 変形後の流体要素に対し-1から1の範囲に正規化された要素座標 $\xi, \eta, \zeta$ 定義する（図2）。要素内任意点における速度ポテンシャ ル $\varphi$ 及びその時間による導関数 $\dot{\varphi}$ を次式のように補間する。

$$
\varphi=\sum_{i}^{8} N_{i} \varphi_{e i}=\mathbf{N} \varphi_{e}, \dot{\varphi}=\sum_{i}^{8} N_{i} \dot{\varphi}_{e i}=\mathbf{N} \dot{\varphi}_{e}
$$

$$
\begin{array}{ll}
\text { ここに、 } & N_{1}=\frac{1}{8}(1-\xi)(1-\eta)(1-\zeta), N_{2}=\frac{1}{8}(1+\xi)(1-\eta)(1-\zeta), \\
& N_{3}=\frac{1}{8}(1+\xi)(1+\eta)(1-\zeta), N_{4}=\frac{1}{8}(1-\xi)(1+\eta)(1-\zeta), \\
& N_{5}=\frac{1}{8}(1-\xi)(1-\eta)(1+\zeta), N_{6}=\frac{1}{8}(1+\xi)(1-\eta)(1+\zeta),
\end{array}
$$
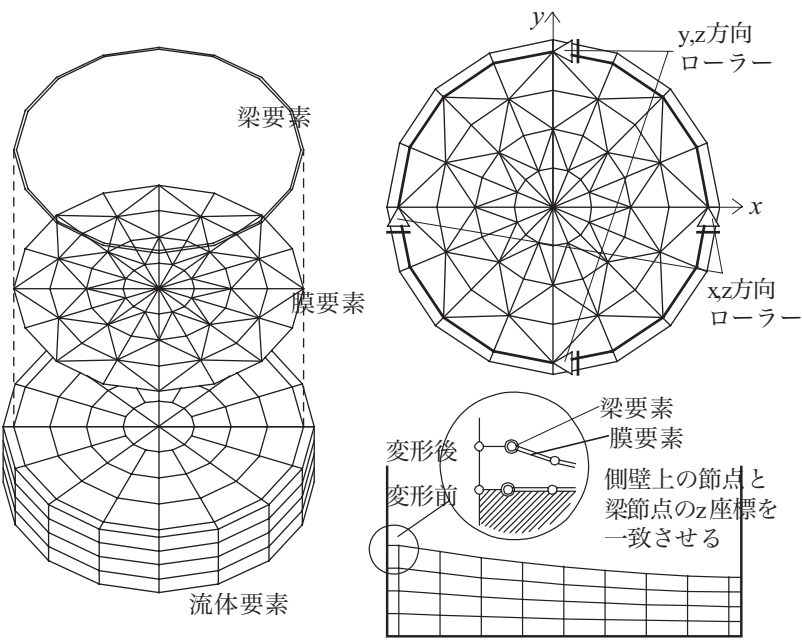

図 1 浮屋根と流体場のモデル化

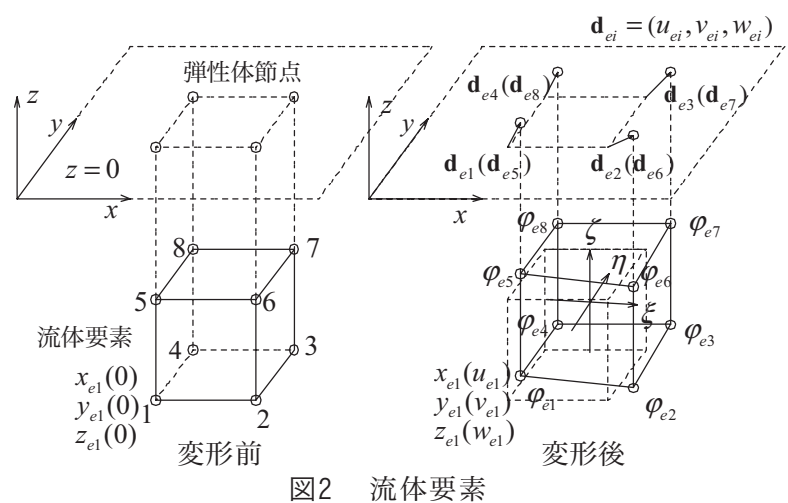

$$
N_{7}=\frac{1}{8}(1+\xi)(1+\eta)(1+\zeta), N_{8}=\frac{1}{8}(1-\xi)(1+\eta)(1+\zeta)
$$

要素内の $x, y, z$ 座標も同様に節点座標を用いて次式のように表す。

$$
x=\mathbf{N} \mathbf{x}_{e}\left(\mathbf{u}_{e}\right), \quad y=\mathbf{N} \mathbf{y}_{e}\left(\mathbf{v}_{e}\right), \quad z=\mathbf{N} \mathbf{y}_{e}\left(\mathbf{w}_{e}\right)
$$

$\varphi$ の $x, y, z$ に関する導関数は、アイソパラメトリック要素の一般的な 定式化に従えば、最終的に次式のように与えられる。

$$
\left\{\begin{array}{l}
\varphi_{, x} \\
\varphi_{, y} \\
\varphi_{, z}
\end{array}\right\}=\frac{1}{\left|\mathbf{J}\left(\mathbf{u}_{e}, \mathbf{v}_{e}, \mathbf{w}_{e}\right)\right|} \mathbf{A}\left(\mathbf{u}_{e}, \mathbf{v}_{e}, \mathbf{w}_{e}\right) \varphi_{e}
$$

ここに、 $\mathbf{J}\left(\mathbf{u}_{e}, \mathbf{v}_{e}, \mathbf{w}_{e}\right)$ はJacobi行列を表し、

$$
\mathbf{J}\left(\mathbf{u}_{e}, \mathbf{v}_{e}, \mathbf{w}_{e}\right)=\left[\begin{array}{lll}
\sum_{i}^{8}\left(\partial N_{i} / \partial \xi\right) x_{e i} & \sum_{i}^{8}\left(\partial N_{i} / \partial \xi\right) y_{e i} & \sum_{i}^{8}\left(\partial N_{i} / \partial \xi\right) z_{e i} \\
\sum_{i}^{8}\left(\partial N_{i} / \partial \eta\right) x_{e i} & \sum_{i}^{8}\left(\partial N_{i} / \partial \eta\right) y_{e i} & \sum_{i}^{8}\left(\partial N_{i} / \partial \eta\right) z_{e i} \\
\sum_{i}^{8}\left(\partial N_{i} / \partial \zeta\right) x_{e i} & \sum_{i}^{8}\left(\partial N_{i} / \partial \zeta\right) y_{e i} & \sum_{i}^{8}\left(\partial N_{i} / \partial \zeta\right) z_{e i}
\end{array}\right]
$$

$\mathbf{A}\left(\mathbf{u}_{e}, \mathbf{v}_{e}, \mathbf{w}_{e}\right)=\left[\begin{array}{c}\mathbf{A}_{x}\left(\mathbf{y}_{e}\left(\mathbf{v}_{e}\right), \mathbf{z}_{e}\left(\mathbf{w}_{e}\right)\right) \\ \mathbf{A}_{y}\left(\mathbf{z}_{e}\left(\mathbf{w}_{e}\right), \mathbf{x}_{e}\left(\mathbf{u}_{e}\right)\right) \\ \mathbf{A}_{z}\left(\mathbf{x}_{e}\left(\mathbf{u}_{e}\right), \mathbf{y}_{e}\left(\mathbf{v}_{e}\right)\right)\end{array}\right]=\left[\begin{array}{lll}\partial|\mathbf{J}| / \partial x_{e 1} & \cdots & \partial|\mathbf{J}| / \partial x_{e 8} \\ \partial|\mathbf{J}| / \partial y_{e 1} & \cdots & \partial|\mathbf{J}| / \partial y_{e 8} \\ \partial|\mathbf{J}| / \partial z_{e 1} & \cdots & \partial|\mathbf{J}| / \partial z_{e 8}\end{array}\right]$

弾性体の梁要素、膜要素はともに幾何学的非線形性を考慮した要 素を用いる。膜要素は歪にグリーン歪を用いた定ひずみ三角形要素 15) とし、梁要素は移動座標系を導入し、剛体変位を除去した変位場 に対して歪を定義した要素 ${ }^{16), 17)}$ を用いた。概要を付録A,Bに示す。

\section{3 沉関数の離散表現と非線形釣合式の導出}

$\mathrm{Luke}^{18)}$ は、流体の圧力の体積積分を汎関数として第一変分を正確 に算定すると、自然境界条件として流体の自由表面上の非線形境界 条件が得られることを示し、剛な容器に入った完全流体のすべての 運動はこの汎関数に基づいて解析できることを明らかにした。一 
方、幾何学的非線形性を考慮した弾性体の運動はハミルトンの原理 を汎関数として解析できる。著者らの一人は、既報14)において上述 の二つのエネルギー関数の和を汎関数とすることで弾性体容器に 入った完全流体の運動を解析可能であることを示した。本報ではこ の汎関数を用いて流体と浮屋根の相互作用を定式化する。浮屋根の 運動エネルギー（質量）を無視すると、流体と浮屋根の相互作用を 支配する汎関数は次式によって表せる ${ }^{14)}$ 。

$I(\phi, u, v, w)=$

$\int_{t_{0}}^{t_{1}} \iiint_{V(u, v, w)} \rho_{f}\left\{\frac{1}{2}\left(\phi_{, x}{ }^{2}+\phi_{, y}{ }^{2}+\phi_{, z}{ }^{2}\right)+\dot{\phi}+a_{x}(t) x+a_{y}(t) y+g z\right\} d V d t$

$-\int_{t_{0}}^{t_{1}}-U(u, v, w) d t$

ここに、 $V$ は流体場、 $\rho_{f}$ は液体質量密度、 $\phi$ は速度ポテンシャ ル、 $a_{x}(t), a_{y}(t)$ はそれぞれ $x, y$ 方向の水平加振加速度、 $g$ は重力加速 度を表す。 $U(u, v, w)$ は浮屋根の歪エネルギーを表す。上式の $\phi$ は才 イラー座標により表現されるが、(2)式で定義した $\varphi$ は評価点（流体 節点）が浮屋根の変位とともに座標を変える為、オイラー座標で表 現されていない。この為、ALE法を適用して $\varphi$ の時間経過による空 間移動を考慮することで、(5)式は次式のように書き換えられる（変 換の詳細については既報12),13)を参照されたい)。

$I(\varphi, u, v, w)=$

$\int_{t_{0}}^{t_{1}} \iiint_{V(u, v, w)} \rho_{f}\left\{\frac{1}{2}\left(\varphi_{, x}{ }^{2}+\varphi_{, y}{ }^{2}+\varphi_{, z}{ }^{2}\right)+\dot{\varphi}-\varphi_{, x} \dot{x}-\varphi_{, y} \dot{y}-\varphi_{, z} \dot{z}+a_{x} x+a_{y} y+g z\right\} d V d t$ $-\int_{t_{0}}^{t_{1}}-U(u, v, w) d t$

上式を前節の要素を用いて離散化すれば、次式のように表現できる。

$I\left(\boldsymbol{\varphi}, \mathbf{u}, \mathbf{v}, \mathbf{w}, \boldsymbol{\theta}_{x}, \boldsymbol{\theta}_{y}, \boldsymbol{\theta}_{z}\right)=\int_{t_{0}}^{t_{1}} \sum_{e} F_{e}\left(\boldsymbol{\varphi}_{e}, \dot{\varphi}_{e}, \mathbf{u}_{e}, \dot{\mathbf{u}}_{e}, \mathbf{v}_{e}, \dot{\mathbf{v}}_{e}, \mathbf{w}_{e}, \dot{\mathbf{w}}_{e}, \boldsymbol{\theta}_{x e}, \boldsymbol{\theta}_{y e}, \boldsymbol{\theta}_{z e}\right) d t(7)$ ここに、 $\boldsymbol{\varphi}=\left(\varphi_{1}, \cdots, \varphi_{N_{f}}\right)^{T}, \mathbf{u} \equiv\left(u_{1}, \cdots, u_{N m}\right)^{T}, \mathbf{v} \equiv\left(v_{1}, \cdots, v_{N m}\right)^{T}$, $\mathbf{w}=\left(w_{1}, \cdots, w_{N m}\right)^{T} \boldsymbol{\theta}_{x}=\left(\theta_{x 1}, \cdots, \theta_{x N b}\right)^{T} \boldsymbol{\theta}_{y}=\left(\theta_{y 1}, \cdots, \theta_{y N b}\right)^{T} \boldsymbol{\theta}_{z}=\left(\theta_{z 1}, \cdots, \theta_{z N b}\right)^{T}$ であり $\theta_{x i}, \theta_{y i}, \theta_{z i}$ は梁要素節点の回転角を、 $N_{f}$ は流体要素の総節点数 $N_{m}\left(>N_{b}\right)$ は膜要素総節点数、 $N_{b}$ は梁要素総節点数を表す。また、

$$
\begin{aligned}
& F_{e}\left(\varphi_{e}, \dot{\varphi}_{e}, \mathbf{u}_{e}, \dot{\mathbf{u}}_{e}, \mathbf{v}_{e}, \dot{v}_{e}, \mathbf{w}_{e}, \dot{\mathbf{w}}_{e}, \boldsymbol{\theta}_{x e}, \boldsymbol{\theta}_{y e}, \theta_{z e}\right)= \\
& \quad \frac{1}{2} \varphi_{e}^{T} \mathbf{k}_{\varphi}\left(\mathbf{u}_{e}, \mathbf{v}_{e}, \mathbf{w}_{e}\right) \boldsymbol{\varphi}_{e}+\mathbf{s}\left(\mathbf{u}_{e}, \mathbf{v}_{e}, \mathbf{w}_{e}\right)^{T} \dot{\varphi}_{e} \\
& \quad-\boldsymbol{\varphi}_{e}^{T} \mathbf{c}_{x 1}\left(\mathbf{v}_{e}, \mathbf{w}_{e}\right) \dot{\mathbf{u}}_{e}-\boldsymbol{\varphi}_{e}^{T} \mathbf{c}_{y 1}\left(\mathbf{w}_{e}, \mathbf{u}_{e}\right) \dot{\mathbf{v}}_{e}-\varphi_{e}^{T} \mathbf{c}_{z 1}\left(\mathbf{u}_{e}, \mathbf{v}_{e}\right) \dot{\mathbf{w}}_{e} \\
& \quad+a_{x} \mathbf{s}\left(\mathbf{u}_{e}, \mathbf{v}_{e}, \mathbf{w}_{e}\right)^{T} \mathbf{x}_{e}\left(\mathbf{u}_{e}\right)+a_{y} \mathbf{s}\left(\mathbf{u}_{e}, \mathbf{v}_{e}, \mathbf{w}_{e}\right)^{T} \mathbf{y}_{e}\left(\mathbf{v}_{e}\right)+g \mathbf{s}\left(\mathbf{u}_{e}, \mathbf{v}_{e}, \mathbf{w}_{e}\right)^{T} \mathbf{z}_{e}\left(\mathbf{w}_{e}\right) \\
& \quad+U_{e}^{m}\left(\mathbf{u}_{e}, \mathbf{v}_{e}, \mathbf{w}_{e}\right)+U_{e}^{b}\left(\mathbf{u}_{e}, \mathbf{v}_{e}, \mathbf{w}_{e}, \boldsymbol{\theta}_{x e}, \boldsymbol{\theta}_{y e}, \boldsymbol{\theta}_{z e}\right) \\
& \mathbf{k}_{\varphi}\left(\mathbf{u}_{e}, \mathbf{v}_{e}, \mathbf{w}_{e}\right)=\rho_{f} \int_{-1}^{1} \int_{-1}^{1} \int_{-1}^{1} \mathbf{A}\left(\mathbf{u}_{e}, \mathbf{v}_{e}, \mathbf{w}_{e}\right)^{T} \mathbf{A}\left(\mathbf{u}_{e}, \mathbf{v}_{e}, \mathbf{w}_{e}\right) \frac{1}{\left|\mathbf{J}\left(\mathbf{u}_{e}, \mathbf{v}_{e}, \mathbf{w}_{e}\right)\right|} d \xi d \eta d \zeta \\
& \mathbf{s}\left(\mathbf{u}_{e}, \mathbf{v}_{e}, \mathbf{w}_{e}\right)=\rho_{f} \int_{-1}^{1} \int_{-1}^{1} \int_{-1}^{1} \mathbf{N}^{T}\left|\mathbf{J}\left(\mathbf{u}_{e}, \mathbf{v}_{e}, \mathbf{w}_{e}\right)\right| d \xi d \eta d \zeta \\
& \mathbf{c}_{x 1}\left(\mathbf{v}_{e}, \mathbf{w}_{e}\right)=\rho_{f}\left(\int_{-1}^{1} \int_{-1}^{1} \int_{-1}^{1} \mathbf{A}_{x}\left(\mathbf{v}_{e}, \mathbf{w}_{e}\right)^{T} \mathbf{N} d \xi d \eta d \zeta\right) \mathbf{H}_{x} \\
& \mathbf{c}_{y 1}\left(\mathbf{w}_{e}, \mathbf{u}_{e}\right)=\rho_{f}\left(\int_{-1}^{1} \int_{-1}^{1} \int_{-1}^{1} \mathbf{A}_{y}\left(\mathbf{w}_{e}, \mathbf{u}_{e}\right)^{T} \mathbf{N} d \xi d \eta d \zeta\right) \mathbf{H}_{y} \\
& \mathbf{c}_{z 1}\left(\mathbf{u}_{e}, \mathbf{v}_{e}\right)=\rho_{f}\left(\int_{-1}^{1} \int_{-1}^{1} \int_{-1}^{1} \mathbf{A}_{z}\left(\mathbf{u}_{e}, \mathbf{v}_{e}\right)^{T} \mathbf{N} d \xi d \eta d \zeta\right) \mathbf{H}_{z}
\end{aligned}
$$

である。 $U_{e}^{m}\left(\mathbf{u}_{e}, \mathbf{v}_{e}, \mathbf{w}_{e}\right), U_{e}^{b}\left(\mathbf{u}_{e}, \mathbf{v}_{e}, \mathbf{w}_{e}, \boldsymbol{\theta}_{x e}, \boldsymbol{\theta}_{y e}, \boldsymbol{\theta}_{z e}\right)$ はそれぞれ膜要素と 梁要素による歪エネルギーの離散化式であるが、一般的な内容であ るため具体的な表現については省略する。(8)式を $\varphi_{e}, \mathbf{u}_{e}, \mathbf{v}_{e}, \mathbf{w}_{e}$, $\theta_{x e}, \theta_{y e}, \theta_{z e}$ に関して変分すると、次の要素釣合式が得られる。

$\delta \varphi_{e}{ }^{T}: \mathbf{k}_{\varphi}\left(\mathbf{u}_{e}, \mathbf{v}_{e}, \mathbf{w}_{e}\right) \varphi_{e}-\mathbf{c}_{x}\left(\mathbf{v}_{e}, \mathbf{w}_{e}\right) \dot{\mathbf{u}}_{e}-\mathbf{c}_{y}\left(\mathbf{w}_{e}, \mathbf{u}_{e}\right) \dot{\mathbf{v}}_{e}-\mathbf{c}_{z}\left(\mathbf{u}_{e}, \mathbf{v}_{e}\right) \dot{\mathbf{w}}_{e}=\mathbf{0}$ $\delta \mathbf{u}_{e}^{T}: \mathbf{c}_{x}\left(\mathbf{v}_{e}, \mathbf{w}_{e}\right)^{T} \dot{\varphi}_{e}+a_{x}\left(\mathbf{H}_{x} \mathbf{s}\left(\mathbf{u}_{e}, \mathbf{v}_{e}, \mathbf{w}_{e}\right)+\mathbf{c}_{x 2}\left(\mathbf{v}_{e}, \mathbf{w}_{e}\right)^{T} \mathbf{x}_{e}\left(\mathbf{u}_{e}\right)\right)$

$+a_{y} \mathbf{c}_{x 2}\left(\mathbf{v}_{e}, \mathbf{w}_{e}\right)^{T} \mathbf{y}_{e}\left(\mathbf{v}_{e}\right)+g \mathbf{c}_{x 2}\left(\mathbf{v}_{e}, \mathbf{w}_{e}\right)^{T} \mathbf{z}_{e}\left(\mathbf{w}_{e}\right)$

$+\frac{1}{2}\left\{\begin{array}{c}\varphi_{e}^{T} \partial \mathbf{k}_{\varphi} / \partial u_{e 1} \varphi_{e} \\ \vdots \\ \varphi_{e}^{T} \partial \mathbf{k}_{\varphi} / \partial u_{e 8} \varphi_{e}\end{array}\right\}-\left\{\begin{array}{c}\varphi_{e}^{T} \partial \mathbf{c}_{y 1} / \partial u_{e 1} \dot{\mathbf{v}}_{e} \\ \vdots \\ \varphi_{e}^{T} \partial \mathbf{c}_{y 1} / \partial u_{e 8} \dot{\mathbf{v}}_{e}\end{array}\right\}-\left\{\begin{array}{c}\varphi_{e}^{T} \partial \mathbf{c}_{z 1} / \partial u_{e 1} \dot{\mathbf{w}}_{e} \\ \vdots \\ \varphi_{e}^{T} \partial \mathbf{c}_{z 1} / \partial u_{e 8} \dot{\mathbf{w}}_{e}\end{array}\right\}$

$+\left(\frac{\partial \mathbf{c}^{T}{ }^{T}}{\partial v_{e i}} \dot{v}_{e i}+\frac{\partial \mathbf{c}_{x 1}{ }^{T}}{\partial w_{e i}} \dot{w}_{e i}\right) \varphi_{e}+\mathbf{q}_{x}^{m}\left(\mathbf{u}_{e}, \mathbf{v}_{e}, \mathbf{w}_{e}\right)+\mathbf{q}_{x}^{b}\left(\mathbf{u}_{e}, \mathbf{v}_{e}, \mathbf{w}_{e}, \theta_{x e}, \boldsymbol{\theta}_{y e}, \boldsymbol{\theta}_{z e}\right)=\mathbf{0}$

$\delta \mathbf{v}_{e}{ }^{T}: \mathbf{c}_{y}\left(\mathbf{w}_{e}, \mathbf{u}_{e}\right)^{T} \dot{\varphi}_{e}+a_{y}\left(\mathbf{H}_{y} \mathbf{s}\left(\mathbf{u}_{e}, \mathbf{v}_{e}, \mathbf{w}_{e}\right)+\mathbf{c}_{y 2}\left(\mathbf{w}_{e}, \mathbf{u}_{e}\right)^{T} \mathbf{y}_{e}\left(\mathbf{v}_{e}\right)\right)$

$+g \mathbf{c}_{y 2}\left(\mathbf{w}_{e}, \mathbf{u}_{e}\right)^{T} \mathbf{z}_{e}\left(\mathbf{w}_{e}\right)+a_{x} \mathbf{c}_{y 2}\left(\mathbf{w}_{e}, \mathbf{u}_{e}\right)^{T} \mathbf{x}_{e}\left(\mathbf{u}_{e}\right)$

$+\frac{1}{2}\left\{\begin{array}{c}\varphi_{e}^{T} \partial \mathbf{k}_{\varphi} / \partial v_{e 1} \varphi_{e} \\ \vdots \\ \varphi_{e}^{T} \partial \mathbf{k}_{\varphi} / \partial v_{e 8} \varphi_{e}\end{array}\right\}-\left\{\begin{array}{c}\varphi_{e}^{T} \partial \mathbf{c}_{z 1} / \partial v_{e 1} \dot{\mathbf{w}}_{e} \\ \vdots \\ \varphi_{e}^{T} \partial \mathbf{c}_{z 1} / \partial v_{e 8} \dot{\mathbf{w}}_{e}\end{array}\right\}-\left\{\begin{array}{c}\varphi_{e}^{T} \partial \mathbf{c}_{x 1} / \partial v_{e 1} \dot{\mathbf{u}}_{e} \\ \vdots \\ \varphi_{e}^{T} \partial \mathbf{c}_{x 1} / \partial v_{e 8} \dot{\mathbf{u}}_{e}\end{array}\right\}$

$+\left(\frac{\partial \mathbf{c}_{y 1}^{T}}{\partial w_{e i}} \dot{w}_{e i}+\frac{\partial \mathbf{c}_{y 1}^{T}}{\partial u_{e i}} \dot{u}_{e i}\right) \boldsymbol{\varphi}_{e}+\mathbf{q}_{y}^{m}\left(\mathbf{u}_{e}, \mathbf{v}_{e}, \mathbf{w}_{e}\right)+\mathbf{q}_{y}^{b}\left(\mathbf{u}_{e}, \mathbf{v}_{e}, \mathbf{w}_{e}, \boldsymbol{\theta}_{x e}, \boldsymbol{\theta}_{y e}, \boldsymbol{\theta}_{z e}\right)=\mathbf{0}$

$\delta \mathbf{w}_{e}^{T}: \mathbf{c}_{z}\left(\mathbf{u}_{e}, \mathbf{v}_{e}\right)^{T} \dot{\boldsymbol{\varphi}}_{e}+a_{z}\left(\mathbf{H}_{z} \mathbf{s}\left(\mathbf{u}_{e}, \mathbf{v}_{e}, \mathbf{w}_{e}\right)+\mathbf{c}_{z 2}\left(\mathbf{u}_{e}, \mathbf{v}_{e}\right)^{T} \mathbf{z}_{e}\left(\mathbf{w}_{e}\right)\right)$

$+a_{x} \mathbf{c}_{z 2}\left(\mathbf{u}_{e}, \mathbf{v}_{e}\right)^{T} \mathbf{x}_{e}\left(\mathbf{u}_{e}\right)+a_{y} \mathbf{c}_{z 2}\left(\mathbf{u}_{e}, \mathbf{v}_{e}\right)^{T} \mathbf{y}_{e}\left(\mathbf{v}_{e}\right)$

$+\frac{1}{2}\left\{\begin{array}{c}\varphi_{e}^{T} \partial \mathbf{k}_{\varphi} / \partial w_{e 1} \varphi_{e} \\ \vdots \\ \varphi_{e}^{T} \partial \mathbf{k}_{\varphi} / \partial w_{e 8} \varphi_{e}\end{array}\right\}-\left\{\begin{array}{c}\varphi_{e}^{T} \partial \mathbf{c}_{x 1} / \partial w_{e 1} \dot{\mathbf{u}}_{e} \\ \vdots \\ \varphi_{e}^{T} \partial \mathbf{c}_{x 1} / \partial w_{e 8} \dot{\mathbf{u}}_{e}\end{array}\right\}-\left\{\begin{array}{c}\varphi_{e}^{T} \partial \mathbf{c}_{y 1} / \partial w_{e 1} \dot{\mathbf{v}}_{e} \\ \vdots \\ \varphi_{e}^{T} \partial \mathbf{c}_{y 1} / \partial w_{e 8} \dot{v}_{e}\end{array}\right\}$

$+\left(\frac{\partial \mathbf{c}_{z 1}{ }^{T}}{\partial u_{e i}} \dot{u}_{e i}+\frac{\partial \mathbf{c}_{z 1}{ }^{T}}{\partial 1_{e i}} \dot{v}_{e i}\right) \varphi_{e}+\mathbf{q}_{z}^{m}\left(\mathbf{u}_{e}, \mathbf{v}_{e}, \mathbf{w}_{e}\right)+\mathbf{q}_{z}^{b}\left(\mathbf{u}_{e}, \mathbf{v}_{e}, \mathbf{w}_{e}, \boldsymbol{\theta}_{x e}, \boldsymbol{\theta}_{y e}, \boldsymbol{\theta}_{z e}\right)=\mathbf{0}$

$\delta \theta_{x e}{ }^{T}: \mathbf{q}_{\theta x}^{b}\left(\mathbf{u}_{e}, \mathbf{v}_{e}, \mathbf{w}_{e}, \boldsymbol{\theta}_{x e}, \boldsymbol{\theta}_{y e}, \boldsymbol{\theta}_{z e}\right)=\mathbf{0}$

$\delta \theta_{y e}{ }^{T}: \mathbf{q}_{\theta y}^{b}\left(\mathbf{u}_{e}, \mathbf{v}_{e}, \mathbf{w}_{e}, \theta_{x e}, \boldsymbol{\theta}_{y e}, \theta_{z e}\right)=\mathbf{0}$

$\delta \theta_{z e}{ }^{T}: \mathbf{q}_{\theta z}^{b}\left(\mathbf{u}_{e}, \mathbf{v}_{e}, \mathbf{w}_{e}, \boldsymbol{\theta}_{x e}, \boldsymbol{\theta}_{y e}, \boldsymbol{\theta}_{z e}\right)=\mathbf{0}$

ここに $\mathbf{c}_{x}=\mathbf{c}_{x 1}+\mathbf{c}_{x 2}, \mathbf{c}_{y}=\mathbf{c}_{y 1}+\mathbf{c}_{y 2}, \mathbf{c}_{z}=\mathbf{c}_{z 1}+\mathbf{c}_{z 2}$

$$
\begin{aligned}
& \mathbf{c}_{x 2}\left(\mathbf{v}_{e}, \mathbf{w}_{e}\right)=\rho_{f}\left(\int_{-1}^{1} \int_{-1}^{1} \int_{-1}^{1} \mathbf{N}^{T} \mathbf{A}_{x}\left(\mathbf{v}_{e}, \mathbf{w}_{e}\right) d \xi d \eta d \zeta\right) \mathbf{H}_{x} \\
& \mathbf{c}_{y 2}\left(\mathbf{w}_{e}, \mathbf{u}_{e}\right)=\rho_{f}\left(\int_{-1}^{1} \int_{-1}^{1} \int_{-1}^{1} \mathbf{N}^{T} \mathbf{A}_{y}\left(\mathbf{w}_{e}, \mathbf{u}_{e}\right) d \xi d \eta d \zeta\right) \mathbf{H}_{y}
\end{aligned}
$$$$
\mathbf{c}_{z 2}\left(\mathbf{u}_{e}, \mathbf{v}_{e}\right)=\rho_{f}\left(\int_{-1}^{1} \int_{-1}^{1} \int_{-1}^{1} \mathbf{N}^{T} \mathbf{A}_{z}\left(\mathbf{u}_{e}, \mathbf{v}_{e}\right) d \xi d \eta d \zeta\right) \mathbf{H}_{z}
$$

また、 $\mathbf{q}_{x}^{m}=\partial U_{e}^{m} / \partial \mathbf{u}_{e}, \mathbf{q}_{y}^{m}=\partial U_{e}^{m} / \partial \mathbf{v}_{e}, \mathbf{q}_{z}^{m}=\partial U_{e}^{m} / \partial \mathbf{w}_{e}$ であり膜要素の 復元力に相当する。同様に、 $\mathbf{q}_{x}^{b}=\partial U_{e}^{b} / \partial \mathbf{u}_{e}, \mathbf{q}_{y}^{b}=\partial U_{e}^{b} / \partial \mathbf{v}_{e}$, $\mathbf{q}_{z}^{b}=\partial U_{e}^{b} / \partial \mathbf{w}_{e}, \mathbf{q}_{\theta x}^{b}=\partial U_{e}^{b} / \partial \theta_{x e}, \mathbf{q}_{\theta y}^{b} \equiv \partial U_{e}^{b} / \partial \theta_{y e}, \mathbf{q}_{\theta z}^{b}=\partial U_{e}^{b} / \partial \theta_{z e}$ であり、梁要素の復元力に相当する。また、(9)式の一部には総和規 約が用いられており、下添え字のiはダミーインデックスを表す。 (9)式の釣合式を要素毎に重㸚あわせることで、次式のような系全体 の釣合式が得られる。

$$
\begin{aligned}
& \mathbf{K}_{\varphi} \boldsymbol{\varphi}-\mathbf{C}_{x} \dot{\mathbf{u}}-\mathbf{C}_{y} \dot{\mathbf{v}}-\mathbf{C}_{z} \dot{\mathbf{w}}=\mathbf{0} \\
& \mathbf{C}_{x}{ }^{T} \dot{\boldsymbol{\varphi}}+\mathbf{C}_{x y} \dot{\mathbf{v}}+\mathbf{C}_{x z} \dot{\mathbf{w}}+\mathbf{F}_{x}+\mathbf{R}_{x}+\mathbf{Q}_{x}^{m}+\mathbf{Q}_{x}^{b}=\mathbf{0} \\
& \mathbf{C}_{y}{ }^{T} \dot{\boldsymbol{\varphi}}+\mathbf{C}_{y x} \dot{\mathbf{u}}+\mathbf{C}_{y z} \dot{\mathbf{w}}+\mathbf{F}_{y}+\mathbf{R}_{y}+\mathbf{Q}_{y}^{m}+\mathbf{Q}_{y}^{b} \equiv \mathbf{0} \\
& \mathbf{C}_{z}^{T} \dot{\boldsymbol{\varphi}}+\mathbf{C}_{z x} \dot{\mathbf{u}}+\mathbf{C}_{z y} \dot{\mathbf{v}}+\mathbf{F}_{z}+\mathbf{R}_{z}+\mathbf{Q}_{z}^{m}+\mathbf{Q}_{z}^{b}=\mathbf{0} \\
& \mathbf{Q}_{\theta x}^{b}=\mathbf{0}, \quad \mathbf{Q}_{\theta y}^{b}=\mathbf{0}, \quad \mathbf{Q}_{\theta z}^{b}=\mathbf{0}
\end{aligned}
$$

ここに、例えば $\mathbf{K}_{\varphi}=\stackrel{M}{e}_{e}^{M_{f}} \mathbf{k}_{\varphi}, \mathbf{C}_{x}=\stackrel{M}{e}_{e}^{M_{f}} \mathbf{c}_{x}, \mathbf{Q}_{x}^{m}=\stackrel{A}{e}_{e}^{M_{m}} \mathbf{q}_{x}^{m}, \mathbf{Q}_{x}^{b}=\stackrel{A}{e}_{e}^{M_{b}} \mathbf{q}_{x}^{b}$ $\mathbf{C}_{x y}=\stackrel{M f}{e}_{e}^{M}\left\{\left[\frac{\partial \mathbf{c}_{x 1}^{T}}{\partial v_{e 1}} \varphi_{e} \cdots \frac{\partial \mathbf{c}_{x 1}^{T}}{\partial v_{e 8}} \varphi_{e}\right]-\left[\begin{array}{c}\varphi_{e}^{T} \partial \mathbf{c}_{y 1} / \partial u_{e 1} \\ \vdots \\ \varphi_{e}^{T} \partial \mathbf{c}_{y 1} / \partial u_{e 8}\end{array}\right]\right]^{e}, \mathbf{R}_{x}={ }_{e}^{M} \frac{1}{2}\left\{\begin{array}{c}\varphi_{e}^{T} \partial \mathbf{k}_{\varphi} / \partial u_{e 1} \varphi_{e} \\ \vdots \\ \varphi_{e}^{T} \partial \mathbf{k}_{\varphi} / \partial u_{e 8} \varphi_{e}\end{array}\right\}$ $\mathbf{F}_{x}=\stackrel{M_{e} f}{A}\left\{a_{x}\left(\mathbf{H}_{x} \mathbf{s}+\mathbf{c}_{x 2}{ }^{T} \mathbf{x}_{e}\right)+a_{y} \mathbf{c}_{x 2}{ }^{T} \mathbf{y}_{e}+g \mathbf{c}_{x 2}{ }^{T} \mathbf{z}_{e}\right\}$

であり、A は重㸚合わせを表すアセンブリ演算記号、 $M_{f}, M_{m}, M_{b}$ は、それぞれ流体要素、膜要素、梁要素の要素数を表す。

以上、リッツ法による定式化によって流体場の境界で満たされる べき諸条件を一切意識することなく非線形釣合式が導出された。 (10)式の非線形釣合式とこれら境界条件との対応関係について述べ 
る。(10-1)式は具体的には次のような形式となっている。

$$
\left[\begin{array}{l|l}
\mathbf{K}_{\varphi 11} & \mathbf{K}_{\varphi 12} \\
\hline \mathbf{K}_{\varphi 21} & \mathbf{K}_{\varphi 22}
\end{array}\right]\left\{\frac{\boldsymbol{\varphi}_{s f}}{\boldsymbol{\varphi}_{i n}}\right\}-\left[\frac{\mathbf{C}_{x 1}}{\mathbf{O}}\right] \dot{\mathbf{u}}-\left[\frac{\mathbf{C}_{y 1}}{\mathbf{O}}\right] \dot{\mathbf{v}}-\left[\frac{\mathbf{C}_{z 1}}{\mathbf{O}}\right] \dot{\mathbf{w}}=\mathbf{0}
$$

ここに $\varphi_{s f}$ は自由表面（流体と浮屋根の境界面及び外周のクリアラ ンス表面）上にある節点の速度ポテンシャル、 $\varphi_{i n}$ は自由表面以外 の節点における速度ポテンシャルを意味する。(11)式の上段は流体 と浮屋根の境界面上での運動学的条件に対応しており、下段は夕ン ク底部および側壁における不透過条件および流体場内部の連続の式 に対応している。タンク底部の法線方向は常に鉛直、側壁の法線方 向は常にタンク中心に向い水平であり、浮屋根（自由表面）の変位 によって向きが変わることは無い。この為、要素釣合式の重ね合わ せの結果、 $\dot{\mathbf{u}}, \dot{\mathbf{v}}, \dot{\mathbf{w}}$ の係数マトリクスの下段の部分はすべてゼロと なることを確認している。一方、(10-2,3,4)式が流体と浮屋根の境界 面上での力学的条件に対応することは、式中に弾性体の復元力が含 まれていることからも明らかである。(10-5,6,7)式は流体要素、膜要 素に回転角の変位成分を含まないため、梁要素のみから成る節点 モーメントに関する自己釣合式となっている。(10)式がこれらの境 界条件と厳密に等価な離散化方程式であることを証明することは難 しいが、(10)式の導出過程に離散化以外の近似は与えていないの で、厳密な非線形相互作用が表現されているものと考える。

2.4 非線形釣合式の時間積分

クランク・ニコルソン法を適用して(10)式を時間積分する方法に ついて示す。(10)式を改めて次式のように表現する。

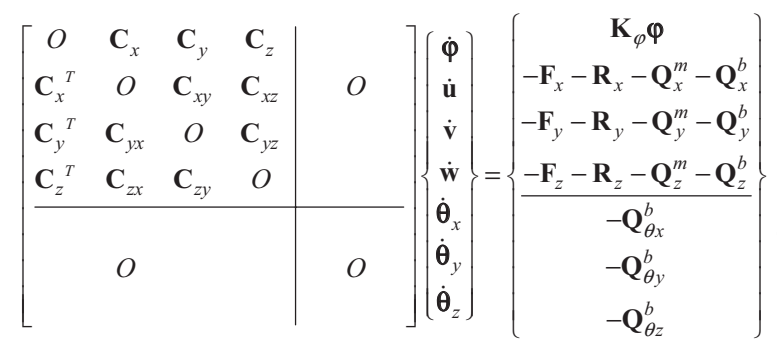

また、上式を次のようにも表す。

\section{$\mathbf{C}(\mathbf{d}) \dot{\mathbf{d}}=\mathbf{F}(\mathbf{d}, t)$}

上式にクランク・ニコルソン法を適用することを考える。クラン ク・ニコルソン法は正規系の 1 階常微分方程式 $\dot{d}=f(d, t)$ を次式の ように差分近似する陰解法である。

$$
\frac{d_{k+1}-d_{k}}{\Delta t}=\frac{1}{2}\left\{f\left(d_{k}, t_{k}\right)+f\left(d_{k+1}, t_{k}+\Delta t\right)\right\}
$$

(12-2)式は、変係数 $\mathbf{C}(\mathbf{d})$ を有する非正規系の方程式となっており、(13) 式をそのまま適用することができない。ここでは変係数 $\mathbf{C}(\mathbf{d})$ を右辺と 同様に中央值として近似し、次の差分近似式を用いることにする。

$$
\frac{1}{2}\left[\mathbf{C}\left(\mathbf{d}_{k}\right)+\mathbf{C}\left(\mathbf{d}_{k+1}\right)\right] \frac{\mathbf{d}_{k+1}-\mathbf{d}_{k}}{\Delta t}=\frac{1}{2}\left\{\mathbf{F}\left(\mathbf{d}_{k}, t_{k}\right)+\mathbf{F}\left(\mathbf{d}_{k+1}, t_{k}+\Delta t\right)\right\}
$$

上式は $\mathbf{d}_{k+1}$ に関して非線形方程式となっているため、 $\mathbf{d}_{k+1}$ を求めるに は反復計算を必要とする。 $t=t_{k}$ の反復計算第 $i$ ステップにおける $\mathbf{d}_{k+1}$ の解候補を $\mathbf{d}_{k+1}^{(i+1)}=\mathbf{d}_{k+1}^{(i)}+\Delta \mathbf{d}^{(i)}$ のように増分表現するものとし、(14)式 にニュートン・ラプソン法を適用すれば、次の修正公式が得られる。

$\left[\frac{1}{2 \Delta t}\left[\mathbf{C}_{k}+\mathbf{C}_{k+1}^{(i)}\right]+\frac{1}{2 \Delta t}\left[\frac{\partial \mathbf{C}_{k+1}^{(i)}}{\partial u_{1}}\left(\mathbf{d}_{k+1}^{(i)}-\mathbf{d}_{k}\right), \cdots, \frac{\partial \mathbf{C}_{k+1}^{(i)}}{\partial u_{N}}\left(\mathbf{d}_{k+1}^{(i)}-\mathbf{d}_{k}\right)\right]\right.$
$\left.-\frac{1}{2}\left[\frac{\partial \mathbf{F}_{k+1}^{(i)}}{\partial u_{1}}, \cdots, \frac{\partial \mathbf{F}_{k+1}^{(i)}}{\partial u_{N}}\right]\right] \Delta \mathbf{d}^{(i)}=-\frac{1}{2 \Delta t}\left[\mathbf{C}_{k}+\mathbf{C}_{k+1}^{(i)}\right]\left(\mathbf{d}_{k+1}^{(i)}-\mathbf{d}_{k}\right)+\frac{1}{2}\left\{\mathbf{F}_{k}+\mathbf{F}_{k+1}^{(i)}\right\}(15)$
ここに、 $\mathbf{C}_{k}=\mathbf{C}\left(\mathbf{d}_{k}\right), \mathbf{C}_{k+1}^{(i)}=\mathbf{C}\left(\mathbf{d}_{k+1}^{(i)}\right), \mathbf{F}_{k}=\mathbf{F}\left(\mathbf{d}_{k}, t_{k}\right)$,

$\mathbf{F}_{k+1}^{(i)}=\mathbf{F}\left(\mathbf{d}_{k+1}^{(i)}, t_{k}+\Delta t\right)$ を意味する。

以上、流体と浮屋根弾性体の非線形相互作用問題の定式化につい て示した。非線形釣合式を線形化し線形固有值解析を行う方法や、 非線形釣合式に比例隇衰を導入する方法など、一連の解析方法につ いては、釣合式に弾性体の復元力が含まれる以外は文献13)とほぼ 同じであるので、こちらを参照されたい。

\section{3 数值解析例}

\section{1 解析モデル}

円筒貯槽は直径 $80 \mathrm{~m}$ 、液体高さ $15 \mathrm{~m}$ とする（図3）。対称性を考慮 し解析は $1 / 2$ の部分で行い（境界条件は図 1 と等価となるように与え る）、要素分割は半径方向に7分割（浮屋根デッキ6分割）、周方向 に12分割、高さ方向に4分割とする。液体密度は $850 \mathrm{~kg} / \mathrm{m}^{3}$ とし、ポン ツーン及びデッキの断面は図4及び表1に示す值とした。

スロッシング解析に先立つて基本的な振動性状を把握するため線 形固有值解析を行い、固有周期の算定を行つた。周期の長いほうか ら10番目までの值を表 2 に示す。同表中には、モード形が分かるよ うに固有モードを半径方向及び周方向にフーリエ級数展開した際に

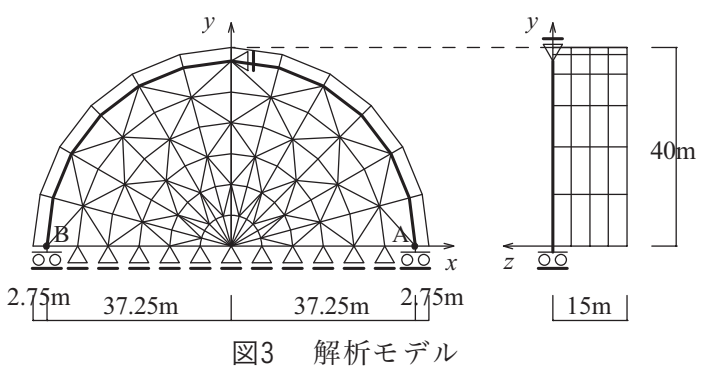

\begin{tabular}{|c|c|c|c|c|}
\hline \multirow{3}{*}{$\begin{array}{l}\text { モード } \\
\text { 次数 }\end{array}$} & \multicolumn{2}{|c|}{ モード形 } & \multirow{3}{*}{$\begin{array}{c}\text { FEM } \\
\text { 周期(s) }\end{array}$} & \multirow{3}{*}{$\begin{array}{l}\text { 自由液面 } \\
\text { 解析解 } \\
\text { 周期(s) }\end{array}$} \\
\hline & 半径 & 周 & & \\
\hline & 方向 & 方向 & & \\
\hline 1 & 1 & 1 & 12.01 & 12.09 \\
\hline 2 & 1 & 2 & 7.76 & $(8.04)$ \\
\hline 3 & 1 & 0 & 7.04 & - \\
\hline 4 & 1 & 3 & 5.68 & $(6.46)$ \\
\hline 5 & 2 & 1 & 5.50 & 5.60 \\
\hline 6 & 2 & $\overline{0}$ & 4.89 & - \\
\hline 7 & 2 & 2 & 4.73 & $(4.93)$ \\
\hline 8 & 1 & 4 & 4.72 & $(5.61)$ \\
\hline 9 & 1 & 5 & 4.19 & $(5.05)$ \\
\hline 10 & 3 & 1 & 4.18 & 4.35 \\
\hline
\end{tabular}

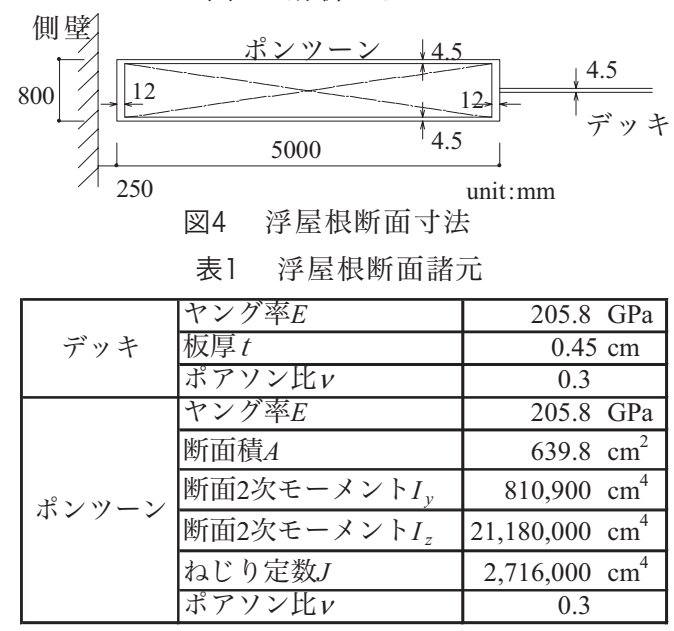

表2 固有周期 


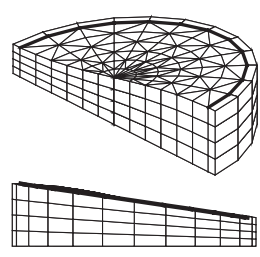

$\phi_{11}, 12.01 \mathrm{sec}$ (1st mode)
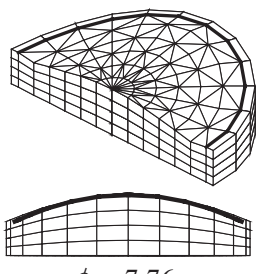
$\phi_{12}, 7.76 \mathrm{sec}$ (2nd mode)

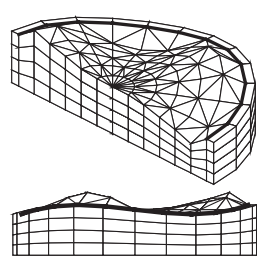

$\phi_{13}, 5.68 \mathrm{sec}$ (4th mode)

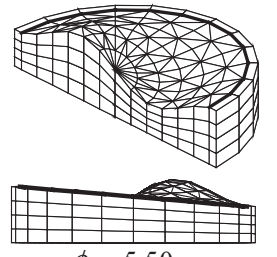

$\phi_{21}, 5.50 \mathrm{sec}$ (5th mode) 図5 固有モード

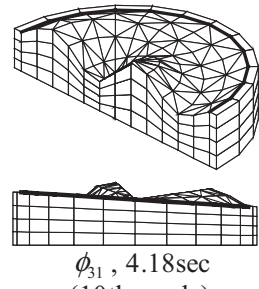

(10th mode)
主要となる展開波次数を記入してある。また周方向展開次数が 1 と なるモードに対し、比較のために自由液面の固有周期の解析解を並 べて示した（周方向展開次数が 1 以外のモードに対しては自由液面 の解析解を参考值として括弧をつけて示した）。シングルデッキ型 浮屋根式タンクの周方向展開次数 1 のモドに対する固有周期は自 由液面の場合と殆ど変わらないことが分かっており6)、本解析にお いても比較的良く一致していることが分かる。代表的な固有モード を図5に示す。図中に記入した $\phi_{i j}$ は固有モードを意味し、下添え字 $i$ は半径方向展開次数、 $j$ は周方向展開次数を表す。 $\phi_{11}, \phi_{21}, \phi_{31}$ では ポンッーンはそれぞれ同一平面上にあり面外曲げ変形を生じない モードであり、一方 $\phi_{12}, \phi_{13}$ ではポンッーンは面外方向に波打ち、 面外曲げ変形を生じるモードとなっている。

\section{2 正弦波入力に対する二次モードスロッシング応答}

入力加速度として、時間に比例して振幅が漸増した後、一定振幅 となる正弦波（図6）を与えて、時刻歴応答解析を行う。正弦波の 振幅は $2.5 \mathrm{gal}$ と $5 \mathrm{gal}$ の 2 ケースとし、周期は $\phi_{21}$ の固有周期付近である $4.7 \mathrm{sec}$ から $6 \mathrm{sec}$ までを $0.1 \mathrm{sec}$ 毎に変化させてそれぞれ解析を行う。減衰 はモード別減衰とし、周期の長いほうから1〜16 番目までのモード に対して $0.5 \%$ 、17番目以降のモードに対して $5 \%$ の減衰を与えた（完 全流体の数值解析では時間の経過や波高が高くなるにつれ、高次の 波が生起し自由表面がジグザグ状になる場合があることが報告され

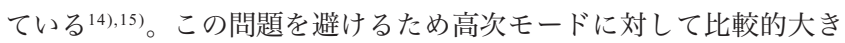
な減衰を与えた。この減衰が以後述べる結果に大きな影響を与えな

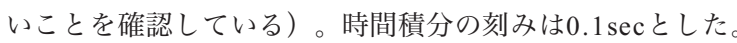

入力周期と最大波高（浮屋根右端部（図 3 の $\mathrm{A}$ 点）の最大鉛直変 位）の関係を、入力加速度が2.5galの結果を記号ロで、5 galの結果を記 号妾を用いて図7に示す。また同図中には、浮屋根に対し幾何学的 非線形性を考慮せず、梁要素及び膜要素を微小変形理論による線形 要素とした場合の結果も同時に示す。入力加速度が $2.5 \mathrm{gal}$ の結果を記 号 $\square 、 5 \mathrm{gal}$ の結果を記号 $\nabla て ゙$ 表す。また、浮屋根の幾何学的非線形挙 動を考慮した結果に対し、デッキに発生した最大の引張主応力を、 2.5 galの時を記号ロで、5galの時を記号更で図8に示す。また参考とし て、デッキに発生したMises応力の最大值について同図中に、2.5 galの 時を記号○で、5 galの時を記号 $\triangle$ でそれぞれ示す。これらの結果か ら、浮屋根の幾何学的非線形挙動を考慮することでデッキに引張力 を生じ（図8）、見掛けの剛性が高くなることで固有周期が短周期
$2.5 \mathrm{gal}, 5 \mathrm{gal}$
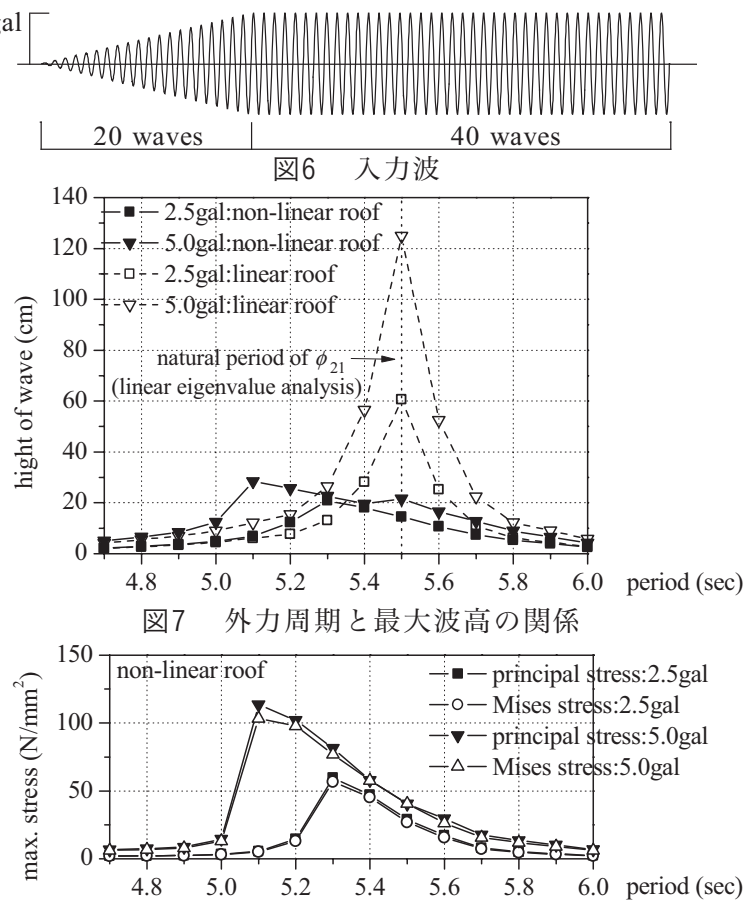

図8 外力周期とデッキ最大応力の関係

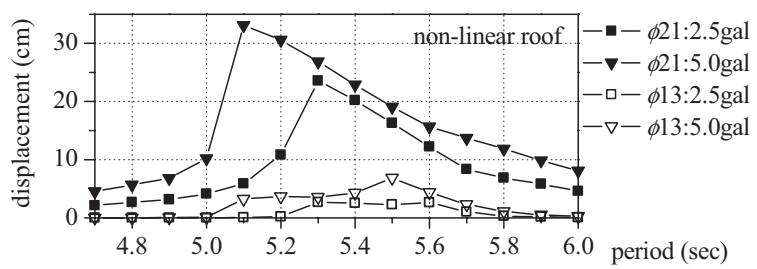

図9 外力周期と $\phi_{21}, \phi_{13}$ の正側最大振幅の関係

側に移動し、応答も小さくなっていることが確認できる（図7）。

一方、浮屋根の幾何学的非線形挙動を考慮した解析では、 $\phi_{21}$ の 振幅が大きくなると、 $\phi_{13}$ の振動が生起する傾向が見られた。この ことについて示す。なお以降では、記述を簡単にする為に、幾何学 的非線形挙動を考慮した浮屋根を非線形浮屋根、線形挙動のみを考 慮した浮屋根を線形浮屋根と呼ぶことにする。

上述の正弦波入力による解析のうち、代表的なものとして外力周 期 $5.4 \mathrm{sec}$ 、外力振幅 $5 \mathrm{gal}$ の時の時刻歷応答波形を、非線形浮屋根の結 果を図10-aに、線形浮屋根の結果を図11-aにそれぞれ示す。縦軸は 浮屋根右端部（図3のA点）の鉛直変位を表す。次にこれらの浮屋 根の変位に対して図5に示した各固有モード成分がそれぞれぞの程 度含まれているかを見るために、変位べクトルを次式のように固有 モードで展開して表現する。

$$
\mathbf{d}=\alpha_{1} \phi_{1}+\alpha_{2} \phi_{2}+\cdots+\alpha_{N} \phi_{N}
$$

ここに、 $N$ は変位の自由度であり、各固有モード $\phi_{i}(i=1, \cdots, N)$ はA 点の鉛直変位が1 となる様に基準化して用いる。 $\phi_{11}, \phi_{21}, \phi_{31}$ 及び $\phi_{13}$ の重み係数の時刻歴波形について、非線形浮屋根の結果を図10$\mathrm{b}, \mathrm{c}, \mathrm{d}, \mathrm{e}$ に、線形浮屋根の結果を図11-b,c,d,eにそれぞれ示す。これらの 図を見ると、線形浮屋根、非線形浮屋根ともに卓越しているのは無 論 $\phi_{21}$ の振動成分であるが、非線形浮屋根の場合では $\phi_{21}$ の振幅が大 きくなるにつれて $\phi_{13}$ の振動が生起していることが分かる。一方、 線形浮屋根の場合ではこのような振動は発生していない。 $\phi_{21}$ と $\phi_{13}$ の固有周期はそれぞれ $5.50 \mathrm{sec} と 5.68 \mathrm{sec}$ であり、両者の固有周期は近 い值となっている（図5）。各外力周期の非線形浮屋根の応答に対 

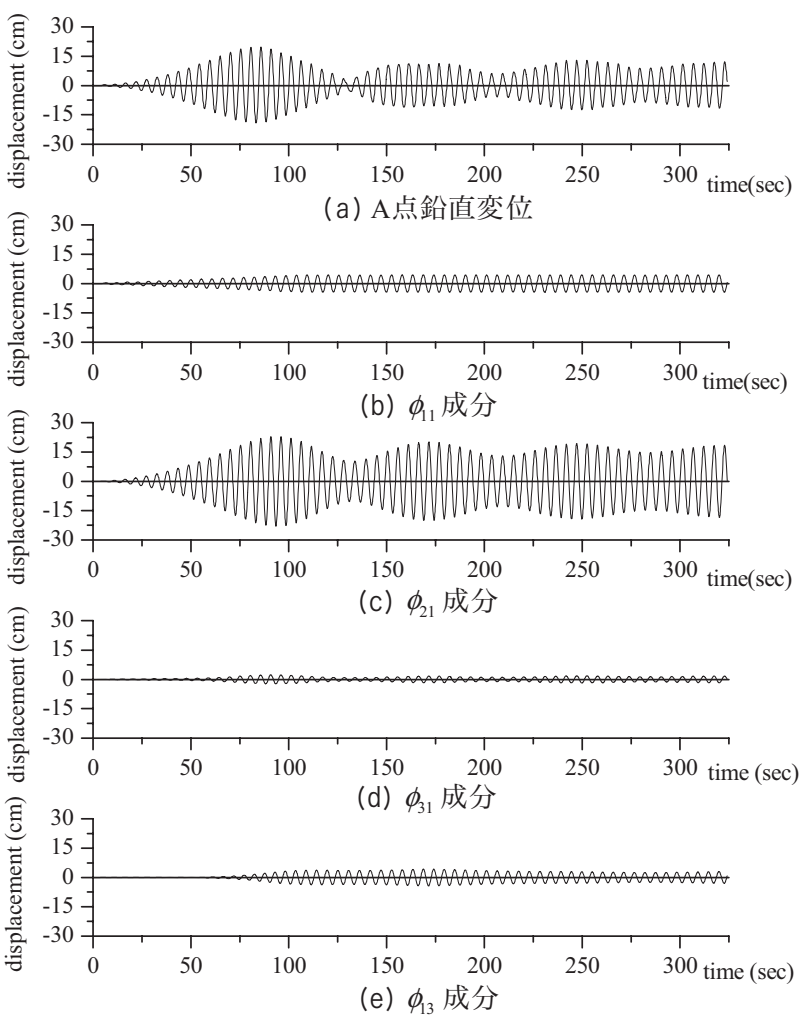

図10 時刻歴応答波形

(浮屋根の幾何学的非線形挙動を考慮, 周期 $5.4 \mathrm{sec}$, 振幅 $5 \mathrm{gal}$ )

して同様にモード展開を行い、 $\phi_{21}$ と $\phi_{13}$ の正側最大振幅と外力周期 の関係を図9に示す。図中、記号吸びマが $\phi_{21}$ の $2.5 \mathrm{gal}$ 及び5 $\mathrm{gal}$ の時の

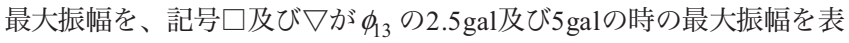
す。図を見ると、 $\phi_{21}$ の振幅が大きく、デッキに応力が発生する外力 周期の範囲 $\left(5 \mathrm{gal}\right.$ の場合5.1 sec 5.6sec付近、図8参照) において $\phi_{13}$ の振 動が生起していることが解かる。 $\phi_{21}$ の振幅増加により、デッキの引 張力によってポンツーンが面外変位を起こし、 $\phi_{21}$ と $\phi_{13}$ の固有周期 が近い為に $\phi_{13}$ の振動が生ずるものと考える。（尚、図 9 を見ると $\phi_{21}$ と $\phi_{13}$ の振幅は比例関係に無く、 $5.5 \mathrm{sec}$ から5.1 $\mathrm{sec} に$ 向かい $\phi_{21}$ の振幅は 上昇するのに対し、 $\phi_{13}$ の振幅は上昇していない。これは $\phi_{13}$ では $\phi_{21}$ に比ベデッキ引張力による見かけの剛性の変化が小さく、 $\phi_{13}$ の固有 周期5.68secから離れるにつれ共振しにくくなる為と考える。）

\section{3 地震波入力に対するスロッシング応答}

入力地震動として、2003 年十勝沖地震の際に苫小牧で観測され た地震波（KNET公開波HKD1290309260450EW）を採用し、時刻歴応 答解析を行う。地震動の加速度時刻歴波形と速度応答スペクトル

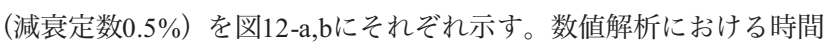

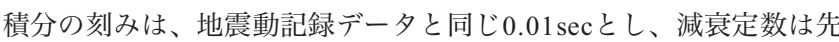
と同様1～16番目までのモードに対して $0.5 \% 、 17$ 番目以降のモード に対して $5 \%$ とした。

浮屋根A点の鉛直変位の時刻歴波形を図13-aに示す。また、線形 浮屋根とした場合の時刻歴波形を図14-aに示す。非線形浮屋根の場 合の最大変位は $103.5 \mathrm{~cm}(t=74.05 \mathrm{sec})$ 、線形浮屋根の場合は $128.3 \mathrm{~cm}(t=86.9 \mathrm{sec})$ であり、応答波形にも差が見られる。前節と同様に これらの変位を固有モードで展開して示す。 $\phi_{11}, \phi_{21}, \phi_{31}$ 及び $\phi_{12}, \phi_{13}$ の重み係数の時刻歴波形を、非線形浮屋根の場合について図13b,c,d,e,fに、線形浮屋根の場合について図14-b,c,d,e,fにそれぞれ示す。線
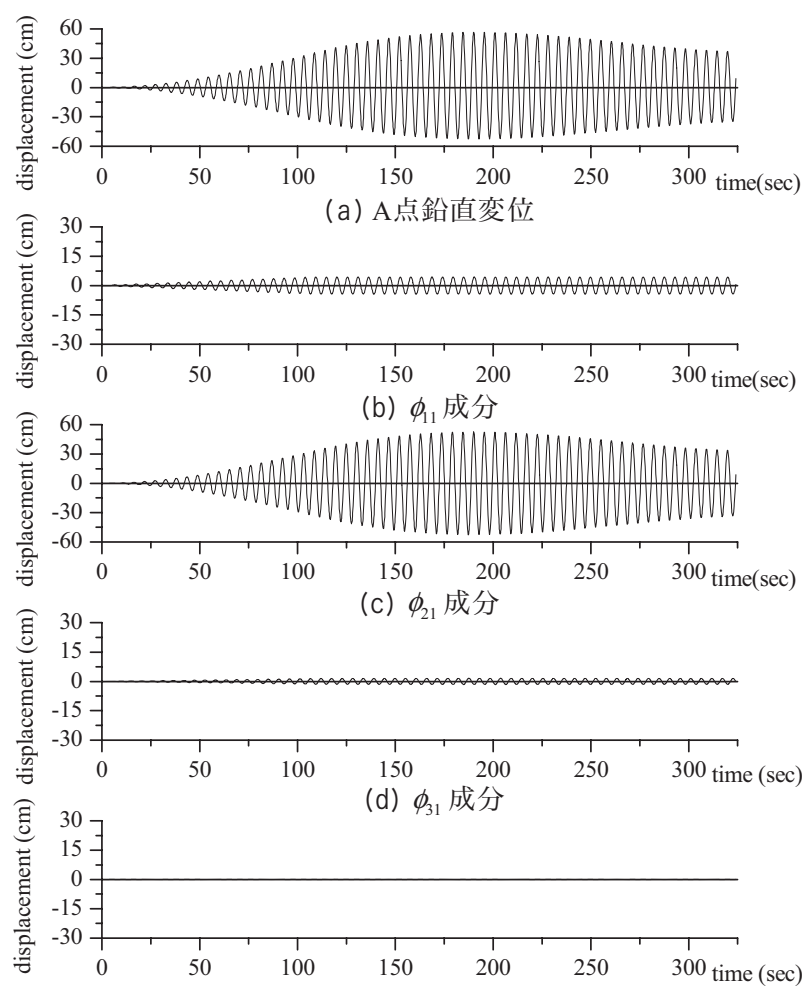

(e) $\phi_{13}$ 成分

図 11 時刻歴応答波形

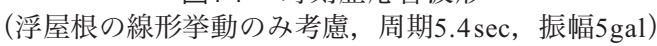

形浮屋根の結果について見てみると、図14-b,cから $\phi_{21}$ に対応する変 位が $\phi_{11}$ に対応する変位と同程度のオーダーとなっており比較的大 きな応答となっている。入力地震動の速度応答スペクトルのピーク が5秒付近にあり（図12）、 $\phi_{21}$ で共振していることが分かる。次に 非線形浮屋根の場合について見てみると（図13-b,c）、 $\phi_{11}$ に対応す る変位は線形浮屋根の場合（図14-b）とほぼ同じであるのに対し、 $\phi_{21}$ に対応する変位は線形浮屋根の場合 (図14-c) の $1 / 2$ 程度に抑え られている。浮屋根の幾何学的非線形性によって $\phi_{21}$ の応答が低減 されていることが分かる。また図13-e,図14-eを見ると、線形浮屋 根、非線形浮屋根ともに $\phi_{12}$ に対応する変位が僅かに生じている。 これは流体が $\phi_{11}$ で共振する際に引き起こされる倍調波振動成分で あり 21),22)、流体の非線形性によって生じる振動成分である。

次に図13-f,図14-fを見てみると、前節と同様に非線形浮屋根の場

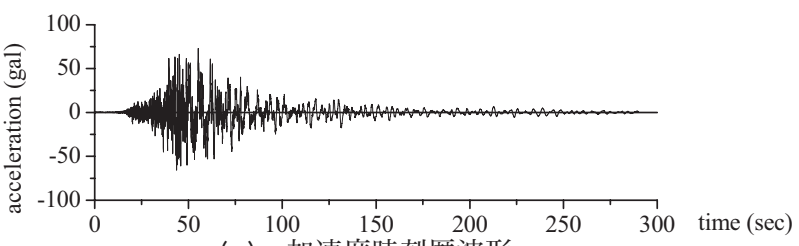
(a) 加速度時刻歴波形

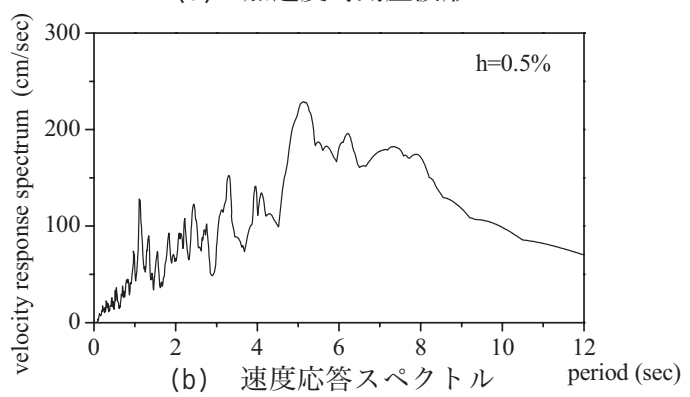

図12 入力地振動 

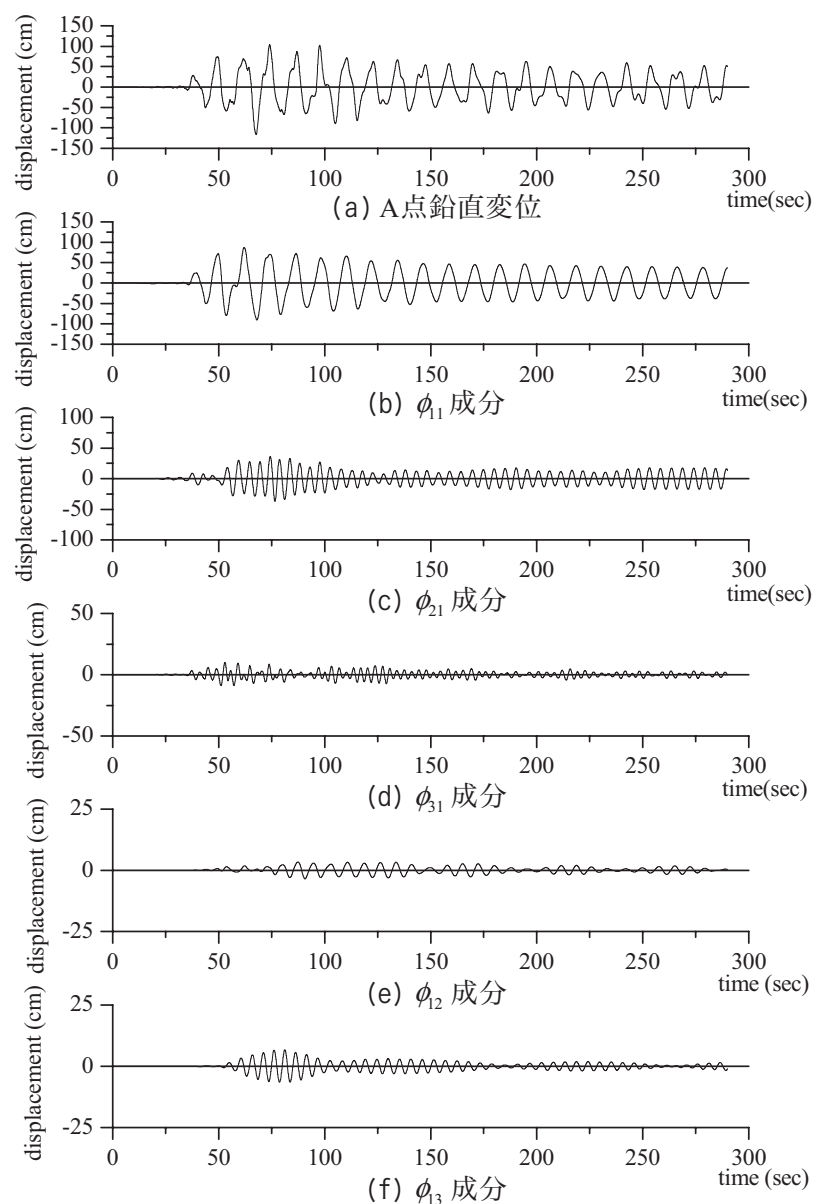

図1 3 時刻歷応答波形（浮屋根の幾何学的非線形挙動を考慮）
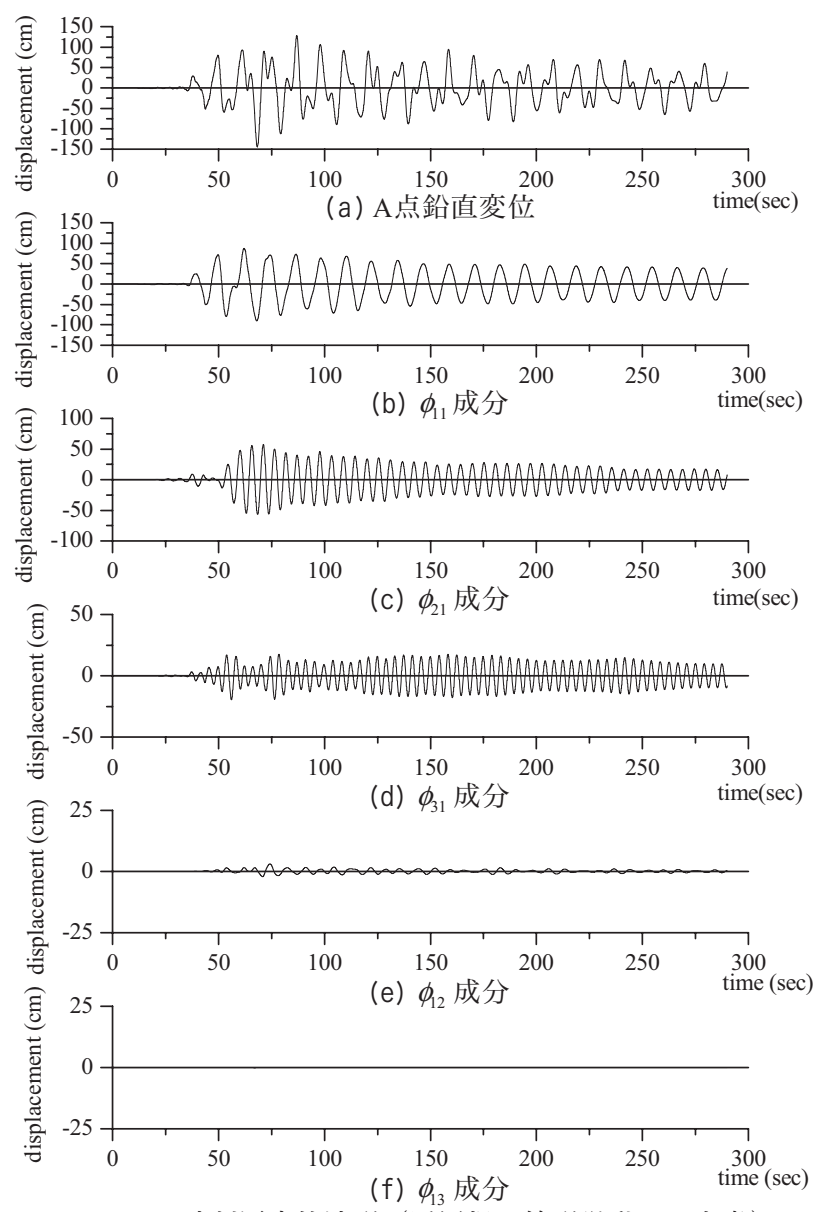

図1 4 時刻歴応答波形（浮屋根の線形挙動のみ考慮）

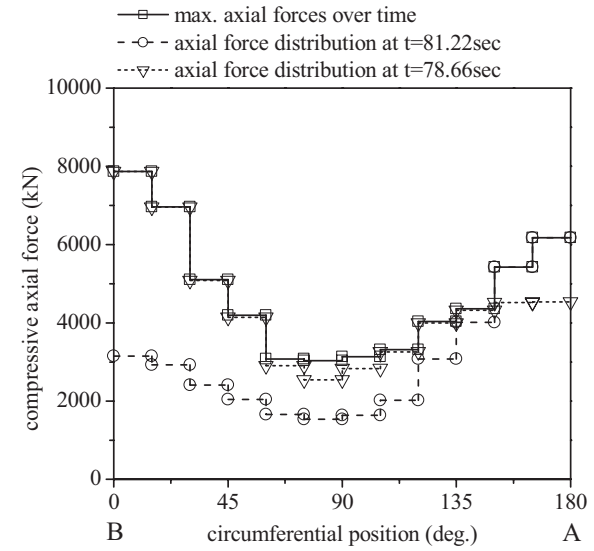

（a）軸圧縮力

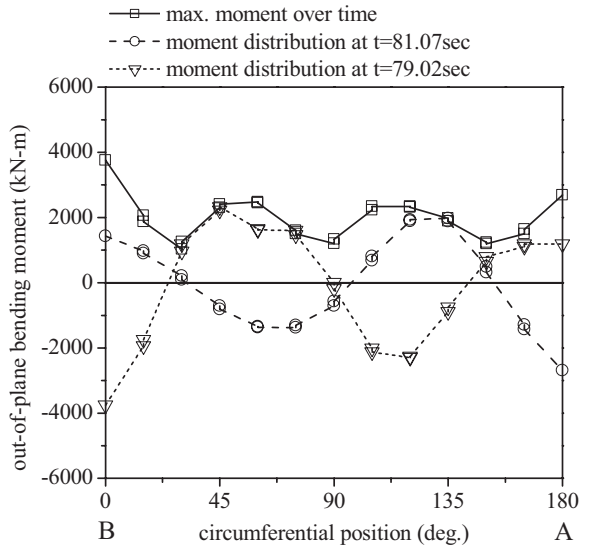

(b) 面外曲げモーメント

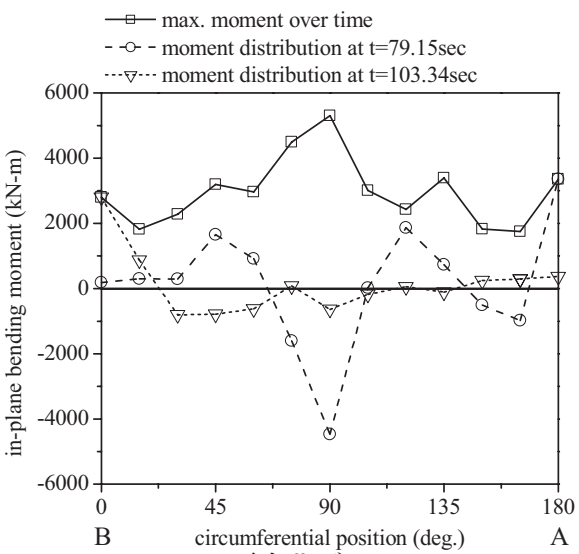

(c) 面内曲げモーメント

図15 ポンッーンの最大断面力分布及び $\mathrm{A}, \mathrm{B}$ 点で最大となる時の断面力分布

合では $\phi_{13}$ の振動を生じており、一方、線形浮屋根の場合では生じ ていない。また図13-eと図13-fの比較から、 $\phi_{13}$ に対応する変位は $\phi_{12}$ に対応する変位よりも大きいことが分かる。 $\phi_{12}, \phi_{13}$ は共にポンッー ンに面外曲げを伴うモードであり、これらの結果から浮屋根の幾何 学的非線形挙動を考慮した場合、ポンッーンに発生する面外曲げ モーメントは主に $\phi_{13}$ の振動成分によって生じることが推測できる。

ポンッーンに発生する軸圧縮力の分布を図15-aに示す。横軸はポ ンッーン上の位置を角度で表現しており、0度は図3のB点、180度は A点に対応する。記号 $\square$ はポンッーンの各点で生じた最大軸圧縮力 を表し、記号○はA点で軸圧縮力が最大となった時刻 $(t=81.22 \mathrm{sec})$ の応力分布を、記号 $\nabla$ は点で最大となった時刻 $(t=78.66 \mathrm{sec})$ の応
力分布を表す。同様に、ポンツーンの面外曲げモーメントの分布と 面内曲げモーメントの分布を図15-b,cにそれぞれ示す。断面力が最大 となる時刻は断面力の種類によってそれぞれ異なっているが、記号 の意味は図15-a と同様である。

図15-bを見ると、A点及びB点で最大となる時 $(t=81.07 \mathrm{sec}$ 及び $79.02 \mathrm{sec} ）$ の面外曲げモーメントの分布はともに周方向3波の分布を 示しており、前述の変位に見られた結果と良く対応する。

面内曲げモーメント (図 $15-\mathrm{c}$ ) については、A 点最大時 $(t=79.15 \mathrm{sec})$ 及びB点最大時 $(t=103.34 \mathrm{sec})$ では応力の分布が異なつ ており、やや複雑な分布を示している。これらの時刻における浮屋 根の変形の様子を図16-a,bに示す。また同図中にはポンッーンがデッ 


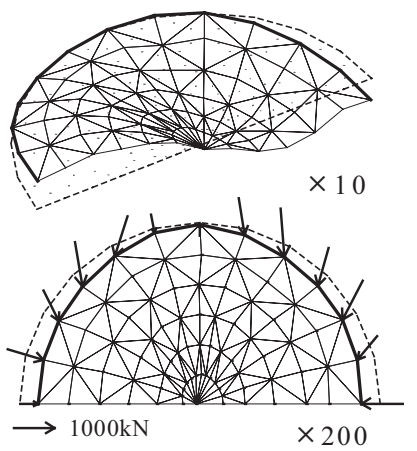

(a) $t=79.15 \mathrm{sec}$
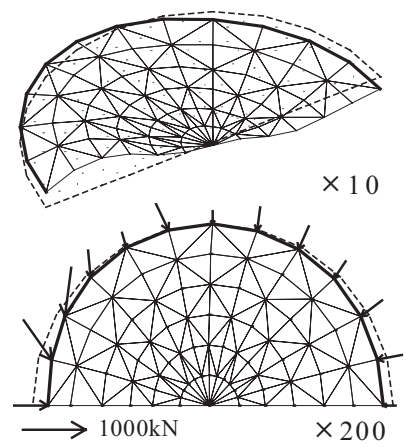

(b) $t=103.34 \mathrm{sec}$

図 16 浮屋根の変形とポンツーンが受ける面内節点力の分布

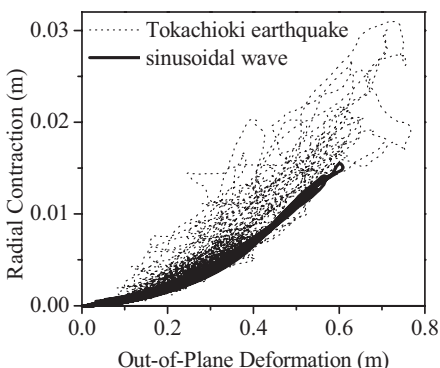

図 17 デッキ面外変形量と

ポンツーン半径方向縮みの関係

キから受ける節点力の分布を矢印で同時に示した（矢印の長さが節 点力の大きさを表す）。これらの図を見るとポンッーンは面内方向 に楕円状に変形しており、変位や節点力はいずれも巨視的には軸対 称分布と周方向2波の分布が卓越している。これに対しポンッーン の面内モーメントの分布は図15-cに示すように周方向高次モードの 影響を受けやすいようである（ポンッーンのみをモデル化したリン グ状フレームに図16の節点力を与えると図15-cの曲げモーメント分 布を示すことを平面骨組解析により確認している）。

デッキの面外変形量とポンッーンの半径方向縮みの関係を図17に 示す。面外変形量と半径方向縮みの算定方法は文献2)に従った。図 中の点線が地震応答時の関係を表しており、実線は 3.2 節で示した 正弦波入力 $(5.1 \mathrm{sec}, 5 \mathrm{gal})$ による応答時の関係を表している。地震 応答の場合では $\phi_{21}$ 以外のモードの影響によってややバラつくもの の相関関係が確認できる。一方、正弦波入力による応答では明瞭な 相関関係が確認できる。このような算定は文献2), 文献11)で行わ机て おり、本報の結果は文献11)の結果と良く一致する。

デッキにおいて最大のMises応力発生時 $(t=78.66 \mathrm{sec})$ における主応

表3 有効断面積及び有効断面係数

\begin{tabular}{|l|r|}
\hline 有効断面積 $A_{e}$ & $265.3 \mathrm{~cm}^{2}$ \\
\hline 有効断面係数 $Z_{y e}$ (面外) & $6,825 \mathrm{~cm}^{3}$ \\
\hline 有効断面係数 $Z_{z e}$ (面内) & $40,050 \mathrm{~cm}^{3}$ \\
\hline
\end{tabular}

表4 数值解析により得られた最大 応力と設計式との比較

\begin{tabular}{|c|c|c|}
\hline & $\begin{array}{c}\text { FEM } \\
\text { 最大值 } \\
\left(\mathrm{N} / \mathrm{mm}^{2}\right)\end{array}$ & $\begin{array}{c}\text { 設計式 } \\
\left(\mathrm{N} / \mathrm{mm}^{2}\right)\end{array}$ \\
\hline 軸応力 $N / A_{e}$ & 296.5 & 212.8 \\
\hline 面外曲げ応力 $M_{y} / Z_{y e}$ & 550.5 & 58.2 \\
(括弧内は線形浮屋根時) & $(28.5)$ & \\
\hline 面内曲げ応力 $M_{z} / Z_{z e}$ & 132.5 & 37.6 \\
\hline
\end{tabular}

力図を図18 に示す。細線は引張応力、太線は圧縮応力を表す。最大 Mises応力は217.8 N/mm²であり、鋼材の基準強度（ $\mathrm{SS} 400, \mathrm{~F}=235 \mathrm{~N} / \mathrm{mm}^{2} ）$ を超える応力は生じていない。

\section{4 地震応答解析結果に対するポンツーン応力の検討}

前節で得られた地震応答解析結果に対し、ポンッーンに発生する 応力について検討する。ポンッーンは薄肉の鋼板によって構成され ている為、圧縮時の局部座屈を考慮した有効断面で応力を評価する 必要がある。ここでは文献2) に倣って有効断面を評価する。

前節の数值解析では、ポンツーンを実在のものと同程度の断面を有 する長方形箱型断面として簡単にモデル化したが、実際のポンツーン では上下板に補強リングが施されている。この為、上下板をそれぞれ およそ三等分する位置に補強リング（L130×130×9）を配置し、図 19-a,bに示す断面を改めて仮定する。図19-a は軸力及び面内曲げに対す る有効断面を、図19-bは面外曲げに対する有効断面（下板引張時）を それぞれ表す（図中黒塗りの部分）。この断面から算定される有効 断面積及び面外方向及び面内方向の有効断面係数を表 3 に示す。

上記の有効断面を用いて、前節の十勝沖地震入力による応答解析 結果に対し、ポンツーンに発生する応力を評価した（前節の解析で は補強リングの断面を無視していることになるが影響は小さいもの と考える）。ポンッーンの各点で生じた最大応力を図 20 に示す。図 中記号 $\square$ は最大軸圧縮応力の分布を、記号○は面外曲げモーメント により生じる最大縁応力を、記号 $\triangle$ は面内曲げモーメントによる最 大縁応力を示す。これらの3つの応力のオーダーを比較すると、面 外曲げ応力が他の応力に比べ最も大きく（最大值 $550.5 \mathrm{~N} / \mathrm{mm}^{2} ）$ 、ま たポンッーンの多くの箇所で鋼材の基準強度を超えている。軸応力 が次に大きく（最大值 $296.5 \mathrm{~N} / \mathrm{mm}^{2}$ ）、面内曲げ応力が最も小さい

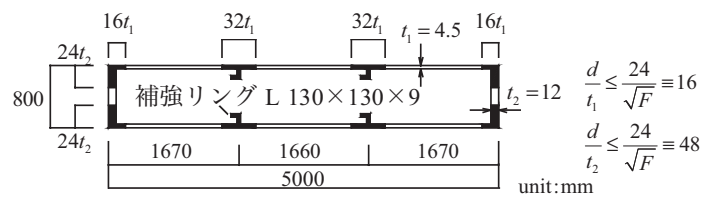

（a）軸力及び面内曲げに対する有効断面

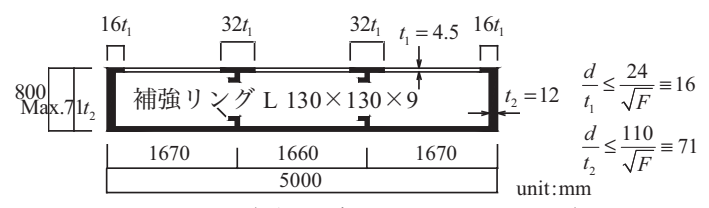

(b) 面外曲げに対する有効断面

図19 有効断面

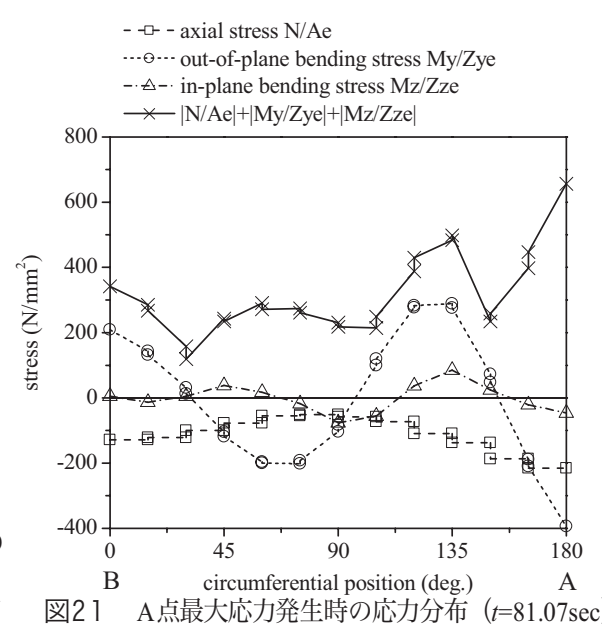

$-\rightarrow-$ - axial stress N/Ae

-...* out-of-plane bending stress My/Zye

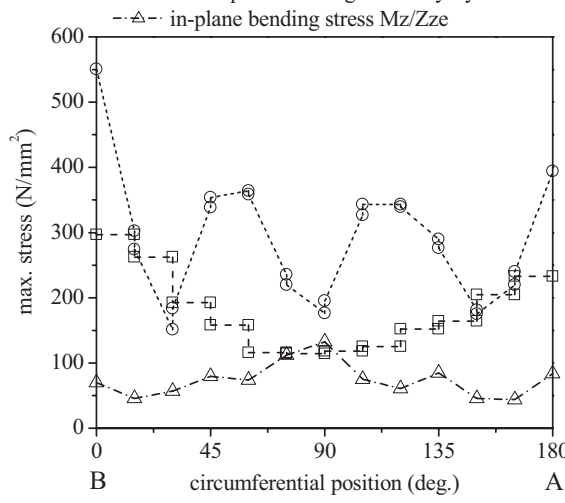

図20 ポンッーンの最大応力の分布 
(最大值 $\left.132.5 \mathrm{~N} / \mathrm{mm}^{2}\right)$ 。次にA点において最大応力を発生した時刻 $(t=81.07 \mathrm{sec})$ におけるポンツーンの応力分布を図 21 に示す。図中記 号 $\square$ は軸応力を、記号○は面外曲げによる緑応力を、記号 $\triangle$ は面内 曲げによる縁応力をぞれぞれ表し、記号×はこれらを合計した值を 表す。ポンッーンの多くの箇所で鋼材の基準強度を超えている。

平成 17 年 4 月の消防法告示の改正 ${ }^{3)}$ では浮屋根がスロッシングに よって損傷を受けない構造とすることが義務付けられたが、浮屋根 の具体的な強度評価の方法（以下設計式と呼ぶ）については、平成 17年1 月14 日に通知された「危険物の規制に関する規則の一部を改 正する省令等の施行について」 ${ }^{23)} に$ 規定されている（設計式は文献 2)で提案されたものと同じである）。この設計式によって算定され る応力と、上で算定された最大応力との比較を行う。結果を表4に 示す。全体に設計式は数值解析より小さな值を示すが、軸応力と面 内曲げ応力については比較的良い対応を示している。一方、面外曲 げ応力は両者で值が大きく異なっている。これは、設計式では $\phi_{11}$ の大振幅時に流体の非線形性によって生じる $\phi_{12}$ の変形を評価する ことで面外曲げ応力を算定しており、本解析結果で見られた $\phi_{13}$ の 変形は考慮されていない為である。参考として、線形浮屋根とした 時の解析結果 (図14) から得られるポンッーンの最大面外曲げ応力 を、同表中括弧内に示した。この場合では $\phi_{13}$ は発生せず $\phi_{12}$ が主要 な変形となる為、設計式と比較的良く対応する。

\section{5 固有周期に対する要素分割及び液高の影響}

前節までの数值解析例では $\phi_{21}$ で共振する際に $\phi_{13}$ の振動が生起す ることを示した。その理由のひとつとして $\phi_{21}$ と $\phi_{13}$ の固有周期の值 が比較的近いことを挙げた。以下ではこれらの固有周期の関係の妥 当性や液高による影響について検討する。

3.1 節で示した解析モデル（直径 $80 \mathrm{~m}$ 、液高 $15 \mathrm{~m}$ ）に対して浮屋根 (弾性体要素) を取り除いて固有值解析を行い、自由表面における 固有周期を算定する (自由表面節点はz方向のみに変位するものと した）。要素分割を変化させ、固有周期の収束の様子を描いたグラ フを図22に示す。横軸は自由度（節点速度ポテンシャル及び自由表

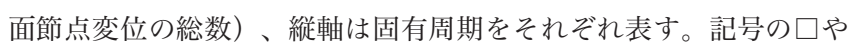
○などで示される点が、固有值解析により得られた值であり、これ らの対応するモードは図中に記入してある。また、図の上部に示し

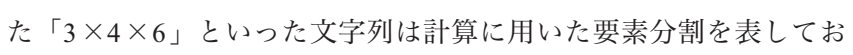
り、最初の数字は液高方向分割数、次の数字は半径方向分割数、最 後の数字は周方向分割数をそれぞれ表す。また、これら固有值解析
により得られた点を結ぶ曲線に漸近する水平点線は次式で表される 自由表面の固有周期の解析解により算定された值を表す。

$$
T_{n m}=2 \pi \sqrt{\frac{R}{\varepsilon_{n m} g} \operatorname{coth}\left(\frac{\varepsilon_{n m} H}{R}\right)}
$$

ただし、 $T_{n m}$ の半径方向次数 $n$ 、周方向次数 $m$ の固有周期を意味し、 $\varepsilon_{n m}$ は第 1 種 $m$ 位ベッセル関数 $J_{m}$ に対し $J_{m}{ }^{\prime}=0$ を満たす $n$ 番目の正根 を表す。また、 $R, H$ はそれぞれ夕ンクの半径及び液高を表す。

自由表面の場合、要素分割を増やすにつれ、固有值解析と解析解 の值は良く一致することが分かる。

次に、浮屋根を有する場合の結果を同様に図 23 に示す。図中の記 号や文字列の意味は先と同じである。図2 2 と比較すると、 $\phi_{11}, \phi_{21} \phi_{31}$ の固有周期は自由表面の場合と殆ど変わらず解析解と良 く一致しているのに対し、 $\phi_{12}, \phi_{13}$ の固有周期は自由液面の解析解 から離れ、周期が幾らか短くなっている。また、 $\phi_{12} よ り \phi_{13}$ の方が (周方向次数が大きいほど）より周期が短くなっていることが分かる。 これは $\phi_{12}, \phi_{13}$ の変形に対し、ポンツーンが曲げ抵抗するためである。

$3.1 、 3.2$ 節の数值解析モデルの要素分割は $4 \times 7 \times 12$ である。図 23 を 見ると固有周期は十分に収束しているとは言い難いが、振動挙動の 大概を捉えるには十分な精度を有していると考える。 $\phi_{21}$ と $\phi_{13}$ の固 有周期は実際よりもより近い值となっているが、時刻歴応答解析で は多くの計算時間を要する為、やむを得ずこの要素分割とした。

次に浮屋根を有する場合に対して液高を変化させて固有值解析を 行い、固有周期の変化を調査した。計算に用いる要素分割は $10 \times 11$ $\times 20$ とした。結果を図 24 に示す。横軸は液高、縦軸は固有周期を表 し、その他の記号 $\square や ○$ 等の意味は先と同様である。また同図中に は、ポンッーンの面外曲げ剛性を 0.5 倍及び 2 倍とした時の $\phi_{13}$ の固有 周期を点線で記入した。図を見ると $\phi_{21}$ と $\phi_{13}$ の固有周期は液高の比 較的広い範囲で近い值を示しており、また、液高が高くなる程これ らの固有周期は近づく傾向にある。従って、前節までに示した数值 解析結果が妥当なものであるとすれば、液高が高いほど本報と同様 の $\phi_{13}$ の振動が生起する可能性が高くなる。低液位の場合に生起す るか否かは調査が必要である。

\section{4 まとめ}

完全流体と弾性体との非線形相互作用問題の定式化を行い、シン グルデッキ型浮屋根を有する円筒液体貯槽の非線形スロッシング解 析を行った。本論文の成果を以下にまとめる。

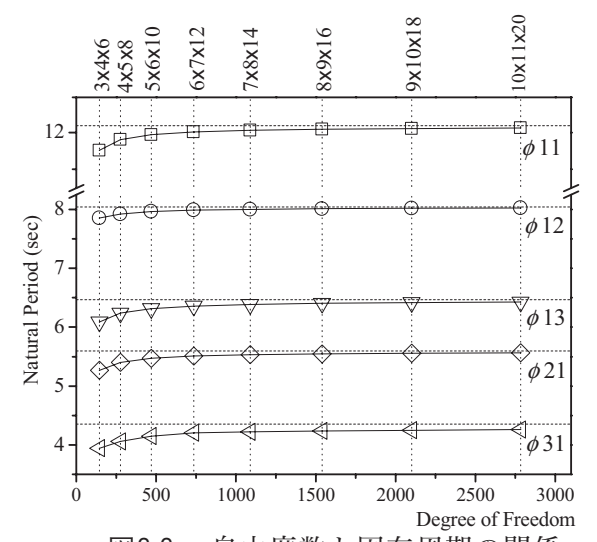

図2 2 自由度数と固有周期の関係 (浮屋根無し)

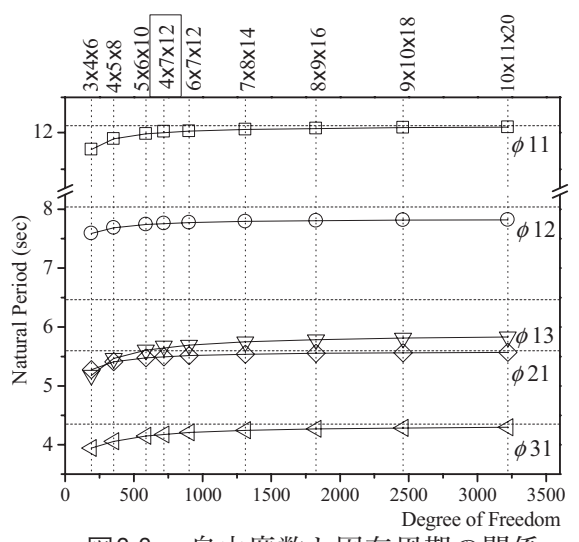

図2 3 自由度数と固有周期の関係 (浮屋根有り)

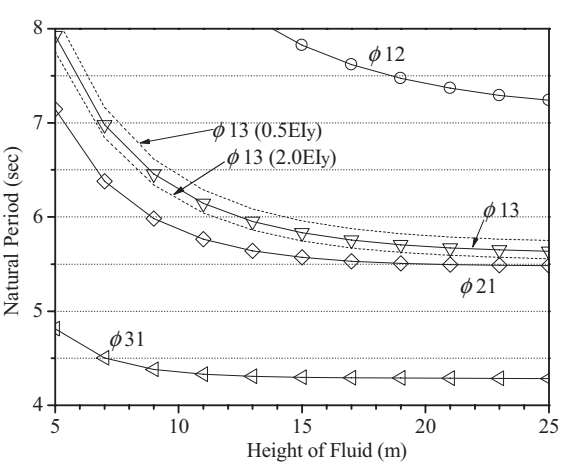

図2 4 液高と固有周期の関係 
1. 著者らが既報12,13)で提案している完全流体における非線形スロッ シングの有限要素解析法を拡張し、浮屋根弾性体との相互作用問 題の定式化を行った。定式化は変分原理に基づいており、煩雑に なりがちなこの問題の非線形釣合式を簡潔に導出して示した。

2. 十勝沖地震において被災したシングルデッキ型浮屋根式タンクと 同規模の数值解析モデルを設定し、提案手法を用いて地震応答解析 を行った。その結果、浮屋根の二次モード（周方向1次、半径方向 2次のモード）の振幅が大きくなるにつれ、浮屋根の幾何学的非線 形性によって周方向3次、半径方向1次の振動モードが生起し、ポン ツーンが破壊するほどの大きな面外曲げモーメントを発生した。

上記の2で述べた結果と同様の報告は既往の研究に見つからなかっ た。実際に二次モードの振動が卓越する際に周方向3次、半径方向1 次の振動モードが生起するか否かについては、実験や他の数值解法 と比較するなどして検証を行い、慎重に議論していく必要がある。

\section{参考文献}

1)危険物保安技術協会 : 平成15年十勝沖地震危険物施設の被害記録，2004.12 2)危険物保安技術協会 : 屋外夕ンク貯蔵所浮屋根審査基準検討会報告書, 2004.9 3)総務省告示第30号 : 危険物の規制に関する技術上の基準の細目を定める告示の 一部を改正する件，2005.4

4)Nakagawa, K.:On the Vibration of an Elevated Water-Tank-II, Technology Reports of the Osaka University, No.117, pp.247-264, 1955

5)山本善之 : 地震による石油夕ンクの液面の動摇と衝撃圧，高圧力，3(1),pp2-8, 1965.1 6)坂井藤一，西村正弘，小川浩：浮屋根式石油貯槽のスロッシング性状に関する 研究，川崎技報, 74号, pp.60-66, 1980

7)松井徹哉：浮屋根式円筒液体貯槽の地震時スロッシング応答の解析，日本建築 学会構造系論文集, No.594, P.167-173, 2005.8

8)松井徹哉 : シングルデッキ型浮屋根を有する円筒液体貯槽の地震時スロッシン グ応答，日本建築学会構造系論文集，No.607, P.101-109, 2006.9

9)三浦正博，菊地務，米川太，人見光夫：浮き屋根式夕ンクのスロッシングシ ミュレーション, 出光技報, VOL.47, NO.3, pp.62-70, 2004

10)内海雅彦, 石田和雄 : 非線形スロッシングによる石油タンク浮き屋根の振動 に関する研究一第1報：内部共振の応力への影響, 圧力技術, 46(2), pp.50-58,2008 11)内海雅彦，石田和雄 : 非線形スロッシングによる石油夕ンク浮き屋根の振動 に関する研究一第3報：デッキの縮みによるポンツーンの楕円化変形，圧力技 術, 46(5), pp.11-19,2008

12)山本憲司，皆川洋一 : 完全流体における非線形スロッシングの有限要素解析法 一二次元矩形容器の解析一, 日本建築学会構造系論文集, No.609, pp. 89-96, 2006.11 13)山本憲司，皆川洋一：完全流体における非線形スロッシングの有限要素解析 法一二次元任意形状容器の解析及び振動実験との比較一, 日本建築学会構造系 論文集，No.634,pp.2119-2127, 2008.12

14)皆川洋一：有限変位場でのポテンシャル流体と弾性体容器の相互作用を支配 する汎関数，日本建築学会構造系論文報告集，No.362, pp.105-115, 1986.4 15)熟津久一郎他：有限要素法ハンドブック II 応用編，培風館，1997 16)佐藤稔夫, 中村恒善 : 新建築学大系36骨組構造の解析, 彰国社, 1982 17)山本憲司，皆川洋一，大森博司：座屈荷重を目的関数とする空間構造の形状 最適化に関する研究，日本建築学会構造系論文集，No.564,pp. 95-102, 2003.2 18)Luke, J. C.: A variational principles for a fluid with a free surface, J. of Fluid Mech., Vol. 27, 395-397, 1967 19)Longuet-Higgins,M.S. and Cokelet, E.D.: The deformation of steep waves on water, I. A numerical method of computation, Proc. R. Soc. Lond., A, 350, pp.1-26, 1976

20)Chen,W., Haroun,M.A., Liu,F. : Large amplitude liquid sloshing in seismically excited tanks, Earthq. Engng. Struct. Dyn., 25, 653-669, 1996

21)大森博司，松井徹哉，日比野浩：液体貯槽における有限振幅液面動摇に関す る研究（その1）基礎方程式の誘導とその円筒形貯槽への適用，日本建築学会 構造系論文報告集，No.375, P.98-105, 1987.5

22)嶋田三朗，山田善一，家村浩和，野田茂 : 円筒タンクの非線形スロッシング解析 に基づく長周期応答スペクトルの推定，土木学会論文集，第368号，pp.383-392, 1986 23)消防危第14号 : 危険物の規制に関する規則の一部を改正する省令等の施行につ いて, 2005.1
付録A 幾何学的非線形性を考慮した膜要素 ${ }^{15}$

要素の形状と変位場の定義を図Aに示す。要素内任意点における変位を、節点 変位 $\left(u_{i}, v_{i}, w_{i}\right)(i=1,2,3)$ を用いて次式により仮定する。

$$
u=\sum_{i=1}^{3} L_{i} u_{i}, \quad v=\sum_{i=1}^{3} L_{i} v_{i}, \quad w=\sum_{i=1}^{3} L_{i} w_{i}
$$

ここに、 $L_{i}(i=1,2,3)$ は三角形の面積座標に対応しており、次式により表される。

$$
L_{i}=\frac{a_{i}+b_{i} x+c_{i} y}{2 S}
$$

$a_{i}=x_{j} y_{k}-x_{k} y_{j}, \quad b_{i}=y_{j}-y_{k}, \quad c_{i}=x_{k}-x_{j}, S \quad$ : 三角形の面積

ここに $(i, j, k)$ は $(1,2,3)$ の巡回置換を表す $((i, j, k)=(1,2,3),(2,3,1),(3,1,2))$

面内の歪として次式のグリーン歪を採用し、仮想仕事の原理により非線形釣 合式を導いている。

$\varepsilon_{x}=\frac{\partial u}{\partial x}+\frac{1}{2}\left\{\left(\frac{\partial u}{\partial x}\right)^{2}+\left(\frac{\partial v}{\partial x}\right)^{2}+\left(\frac{\partial w}{\partial x}\right)^{2}\right\}, \varepsilon_{y}=\frac{\partial v}{\partial y}+\frac{1}{2}\left\{\left(\frac{\partial u}{\partial y}\right)^{2}+\left(\frac{\partial v}{\partial y}\right)^{2}+\left(\frac{\partial w}{\partial y}\right)^{2}\right\}$

$\gamma_{x y}=\frac{\partial v}{\partial x}+\frac{\partial u}{\partial y}+\left(\frac{\partial u}{\partial x}\right)\left(\frac{\partial u}{\partial y}\right)+\left(\frac{\partial v}{\partial x}\right)\left(\frac{\partial v}{\partial y}\right)+\left(\frac{\partial w}{\partial x}\right)\left(\frac{\partial w}{\partial y}\right)$

付録B 幾何学的非線形性を考慮した梁要素16,17

部材 $i j$ が外力を受け $i^{\prime} j^{\prime}$ に変位したものとする(头B)。変形前の要素座標系に おける節点変位ベクトルを次式で表す。

$\mathbf{d}=\left[\begin{array}{llllllllllll}u_{i} & v_{i} & w_{i} & \theta_{x i} & \theta_{y i} & \theta_{z i} & u_{j} & v_{j} & w_{j} & \theta_{x j} & \theta_{y j} & \theta_{z j}\end{array}\right]^{T}$

節点変位べクトル $\mathbf{d}$ から軸方向変位は剛体変位を、回転角は要素座標系で部材 角を除去して定義される材端変位ベクトルを $\mathbf{d}_{e}$ として次式で表す。

$$
\mathbf{d}_{e}=\left[\begin{array}{llllll}
u_{e} & \theta_{e x} & \theta_{e y i} & \theta_{e z i} & \theta_{e y j} & \theta_{e z j}
\end{array}\right]^{T}
$$

ここで $\mathbf{d}$ と $\mathbf{d}_{e}$ には幾何学的に次の関係が成り立つ。

$u_{e}=\sqrt{\left(u_{j}-u_{i}+l\right)^{2}+\left(v_{j}-v_{i}\right)^{2}+\left(w_{j}-w_{i}\right)^{2}}-l$

$\theta_{e x}=\theta_{x j}-\theta_{x i}, \theta_{e y i}=\theta_{y i}-R_{y}, \theta_{e y j}=\theta_{y j}-R_{y}, \theta_{e z i}=\theta_{z i}-R_{z}, \theta_{e z j}=\theta_{z j}-R_{z}$

ここに、 $R_{y}=-\tan ^{-1}\left(\frac{w_{j}-w_{i}}{u_{j}-u_{i}+l}\right), R_{z}=+\tan ^{-1}\left(\frac{v_{j}-v_{i}}{u_{j}-u_{i}+l}\right)$

上式の材端変位 $\mathbf{d}_{e}$ を用いて、材軸上における任意位置の変位を軸方向及び回 転変位を1次、法線方向変位を3次の多項式によって近似する。

$u=\xi u_{e}, \quad \theta=\xi \theta_{e x}, \quad v=l\left(\xi^{3}-2 \xi^{2}+\xi\right) \theta_{e z i}+l\left(\xi^{3}-\xi^{2}\right) \theta_{e z j}$

$w=l\left(-\xi^{3}+2 \xi^{2}-\xi\right) \theta_{e y i}+l\left(-\xi^{3}+\xi^{2}\right) \theta_{e y j} \quad(\xi=x / l)$

要素内任意点における軸方向歪 $\varepsilon_{x}$ および据れにより生じるせん断歪 $\gamma_{x y}, \gamma_{x z}$ を次 式で仮定する。

$\varepsilon_{x}=\varepsilon_{0}-z \phi_{y}-y \phi_{z}, \gamma_{x y}=\left(\frac{\partial \Psi}{\partial y}-z\right) \phi_{x}, \gamma_{x z}=\left(\frac{\partial \Psi}{\partial z}-y\right) \phi_{x}$

ここに

$\varepsilon_{0}=\frac{d u}{d x}+\frac{1}{2}\left\{\left(\frac{d u}{d x}\right)^{2}+\left(\frac{d v}{d x}\right)^{2}+\left(\frac{d w}{d x}\right)^{2}\right\}, \phi_{x}=\frac{d \theta}{d x}, \phi_{y}=\frac{d^{2} v}{d x^{2}}, \phi_{z}=\frac{d^{2} w}{d x^{2}}$

であり、 $\Psi$ はゆが夕関数である。上式歪を用いて、仮想仕事の原理により非線 形釣合式を導いている。
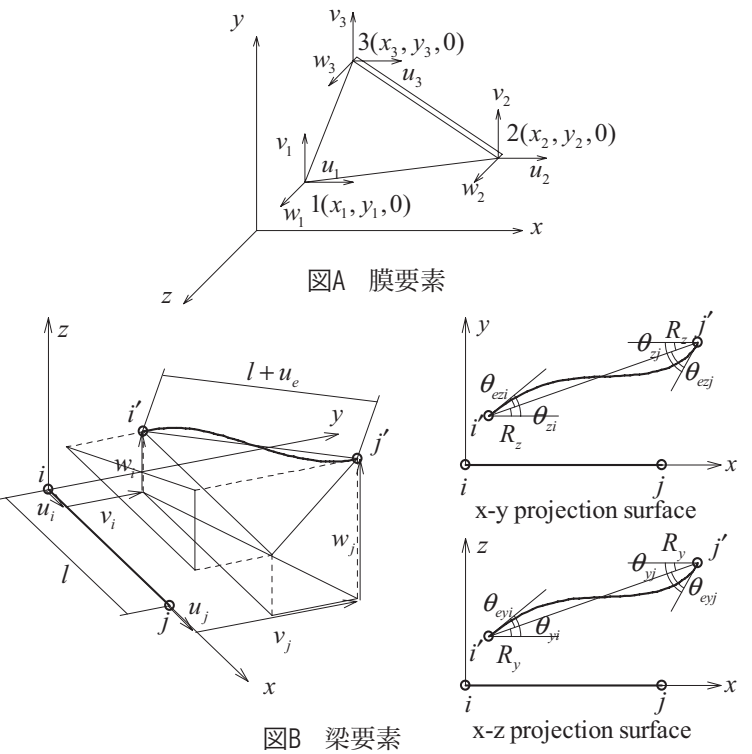

（2009年 1 月 7 日原稿受理, 2009年 6 月 2 日採用決定） 